SJ Quinney College of Law, University of Utah Utah Law Digital Commons

$8-2020$

Association for Molecular Pathology v. Myriad Genetics: A Critical Reassessment

Jorge L. Contreras

Follow this and additional works at: https://dc.law.utah.edu/scholarship

Part of the Intellectual Property Law Commons 


\section{Michigan Technology Law Review}

\section{Association for Molecular Pathology v. Myriad Genetics: A Critical Reassessment}

Jorge L. Contreras

University of Utah S.J. Quinney College of Law

Follow this and additional works at: https://repository.law.umich.edu/mtlr

Part of the Health Law and Policy Commons, Intellectual Property Law Commons, Science and Technology Law Commons, and the Supreme Court of the United States Commons

\section{Recommended Citation}

Jorge L. Contreras, Association for Molecular Pathology v. Myriad Genetics: A Critical Reassessment, 27 MICH. TECH. L. REV. 1 (2020).

Available at: https://repository.law.umich.edu/mtlr/vol27/iss1/2

This Article is brought to you for free and open access by the Journals at University of Michigan Law School Scholarship Repository. It has been accepted for inclusion in Michigan Technology Law Review by an authorized editor of University of Michigan Law School Scholarship Repository. For more information, please contact mlaw.repository@umich.edu. 


\title{
ASSOCIATION FOR MOLECULAR PATHOLOGY V. MYRIAD GENETICS: A CRITICAL REASSESSMENT
}

\author{
Jorge L. Contreras *
}

\begin{abstract}
The Supreme Court's 2013 decision in Association for Molecular Pathology v. Myriad Genetics is an essential piece of the Court's recent quartet of patent eligibility decisions, which also includes Bilski v. Kappos, Mayo v. Prometheus, and Alice v. CLS Bank. Each of these decisions has significantly shaped the contours of patent eligibility under Section 101 of the Patent Act in ways that have been both applauded and criticized. The Myriad case, however, was significant beyond its impact on Section 101 jurisprudence. It was seen, and litigated, as a case impacting patient rights, access to healthcare, scientific freedom, and human dignity. In this article, I offer a close textual analysis of the Myriad decision and respond to both its critics and supporters. I then situate Myriad within the larger context of biotechnology patenting, the commercialization of academic research, and the U.S. healthcare system. In this regard, the failure of public institutions and governmental agencies to constrain the private exploitation of publicly-funded innovations contributed as much to the healthcare access disparities highlighted by the case as the overly broad protection afforded by the Patent and Trademark Office to genetic inventions. I conclude with observations about the ways that cases like Myriad exemplify the manner in which the common law evolves, particularly in areas of rapid technological change.
\end{abstract}

\footnotetext{
Presidential Scholar and Professor, University of Utah S.J. Quinney College of Law; Adjunct Professor, Department of Human Genetics, University of Utah School of Medicine. J.D., Harvard Law School; B.S.E.E., B.A., Rice University. This article has benefited from discussion at the University of Michigan School of Law 2019 IP Workshop as well as helpful comments and suggestions by Rebecca Eisenberg, Kevin Noonan, Arti Rai, Joshua Sarnoff and Jacob Sherkow. Research assistance by Sydney Hecimovich is greatly appreciated. The issues discussed in this article are further elaborated in the author's forthcoming book, The Genome Defense: Inside the EPIC Legal BAtTle to Determine Who OWNS Your DNA (forthcoming 2021).
} 


\section{TABLE OF CONTENTS}

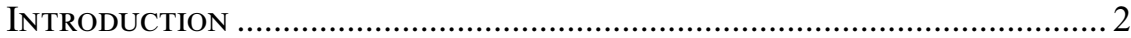

I. Cancer, Genes, and the Genetic Diagnostics Business........... 4

A. The Long Road to BRCA......................................................... 4

B. Gene Patenting in the United States......................................... 9

C. The Inception of Myriad: Bayh-Dole, University Patents, and the Cold Fusion Debacle ................................................ 13

D. Myriad's BRCA Patents....................................................... 15

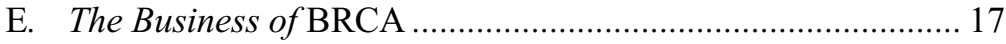

1. Consolidation of the BRCA Testing Market ..................... 17

2. BRACAnalysis - Cost and Coverage.................................. 18

II. AMP v. Myriad-THE LiTIGATION .................................................. 20

A. Southern District of New York .............................................. 20

B. Court of Appeals for the Federal Circuit................................ 21

C. The Supreme Court .............................................................. 24

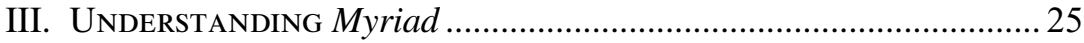

A. Three Layers of Meaning....................................................... 26

B. Does This Story Have A Villain? ............................................ 27

C. The Supreme Court's Opinion: Baby-Splitting Generally

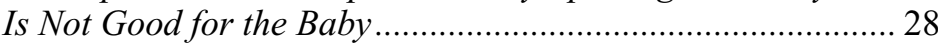

1. Distinctions with a Difference ….....................................29

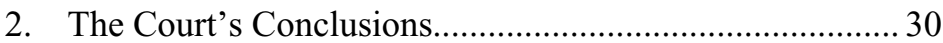

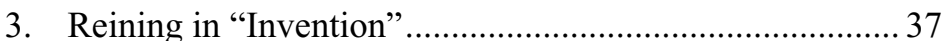

D. Hold the Mayo: What About Methods? .................................... 39

E. All Hail, Alma Mater ........................................................... 42

F. Paying it Forward................................................................ 51

CONCLUSION: MYRIAD AND THE MAKING OF COMMON LAW ….................... 52

\section{INTRODUCTION}

The U.S. Supreme Court's 2013 decision in Association for Molecular Pathology v. Myriad Genetics ${ }^{1}$ is part of the Court's recent quartet of patent eligibility decisions, which also includes Bilski v. Kappos, ${ }^{2}$ Mayo v. Prometheus, ${ }^{3}$ and Alice v. CLS Bank. ${ }^{4}$ Each of these decisions has significantly shaped the contours of patent eligibility under Section 101 of the Patent

1. 569 U.S. $576(2013)$.

2. 561 U.S. $593(2010)$.

3. 566 U.S. $66(2012)$.

4. 573 U.S. 208 (2014). 
$\mathrm{Act}^{5}$ in ways that have been alternately applauded and criticized by lower courts, ${ }^{6}$ the patent bar, ${ }^{7}$ and academia. ${ }^{8}$ In related but different ways, each decision attempts to push the boundaries of judicial exclusions of patentable subject matter. The inventions in Bilski and Alice involved abstract ideas, those in Mayo involved mental steps, while those in Myriad involved "products of nature."

The Myriad decision, however, was significant beyond its impact on Section 101 jurisprudence. The Court's denial of patent protection for naturally occurring human DNA sequences led many to question the United States' competitiveness in the biotechnology sector. Patent attorneys railed against the Court's reversal of decades of established patent law and practice. ${ }^{10}$ The case was a major vindication for patients, advocacy groups, physicians, and researchers. ${ }^{11}$ And, virtually overnight, it transformed the market for cancer genetic testing.

5. 35 U.S.C. $\S 101$

6. See, e.g., Athena Diagnostics, Inc. v. Mayo Collaborative Services LLC, 915 F.3d 743 (Fed. Cir. 2019).

7. See, e.g., Paul Cole, Patent Eligibility Under Section 101: Has the United States 'TRIPPED' Up?, IPWATCHDOG (Sept. 24, 2019), https://www.ipwatchdog.com/2019/09/24 /patent-eligibility-section-101-u-s-tripped; Ted G. Dane, Are the Federal Circuit's Recent Section 101 Decisions a Specific Improvement in Patent Eligibility Law?, 26 FED. CIR. B.J. 331 (2017).

8. See, e.g., Jeffrey A. Lefstin, Peter S. Menell \& David O. Taylor, Final Report of the Berkeley Center for Law \& Technology Section 101 Workshop: Addressing Patent Eligibility Challenges, 33 BERKELEY TECH. L.J. 551 (2018); Kevin Madigan \& Adam Mossoff, Turning Gold to Lead: How Patent Eligibility Doctrine Is Undermining U.S. Leadership in Innovation, 24 Geo. Mason L. ReV. 939 (2017); David O. Taylor, Confusing Patent Eligibility, 84 TenN. L. REV. 157 (2016); Christopher M. Holman, Patent Eligibility Post-Myriad: A Reinvigorated Judicial Wildcard of Uncertain Effect, 82 GEO. WASH. L. REV. 1796 (2014).

9. The literature discussing the "product of nature" doctrine in the context of gene patenting is voluminous. See, e.g., Christopher Beauchamp, Patenting Nature: A Problem of History, 16 StAn. TeCH. L. REV. 257, 268-71 (2013); Dan L. Burk, The Curious Incident of the Supreme Court in Myriad Genetics, 90 Notre DAME L. REV. 505, 513-20 (2014); John M. Golden \& William M. Sage, Are Human Genes Patentable? The Supreme Court Says Yes and No, 32 Health AfF. 1343 (2013); Arti K. Rai \& Robert Cook-Deegan, Moving Beyond "Isolated" Gene Patents, 341 SCIENCE 137, 138 (2013); Matthew M. Karlan, Note, Patent Policy, Natural Products, and the Gene Patent Debate: Seeking the Proper Judicial Mode of Analysis, 67 N.Y.U. ANN. SURV. AM. L. 95, 98-112 (2011).

10. See, e.g., AIPLA Is Concerned About Impact of Supreme Court's Decision in Myriad, Am. InTELl. Prop. L. Ass'N. (Jun. 13, 2013), https://myemail.constantcontact.com/AIPLA-is-Concerned-About-Impact-of-Supreme-Court-Decision-in-

Myriad.html?soid=1109295819134\&aid=Ff4y5mahkG4 ("AIPLA is concerned that . . today's opinion may throw into question patent protection for important technology that is critical to improving health for the public"); Press Release, Jim Greenwood, BIOTECH. INDUS. ORG., Statement on U.S. Supreme Court Review of Isolated DNA Patents (Jun. 13, 2013), archive.bio.org/media/press-release/statement-us-supreme-court-review-isolated-dna-patents ("the Supreme Court's decision today represents a troubling departure from decades of judicial and Patent and Trademark Office precedent").

11. See, e.g., Jeffrey M. Perkel, Gene Patents Decision: Everybody Wins, SCIENTIST (Jun. 18, 2013), https://www.the-scientist.com/daily-news/gene-patents-decision-everybody- 
In this article, I offer a close textual analysis of the Supreme Court's Myriad decision, responding to both its critics and its supporters. I then situate Myriad within the larger context of biotechnology patenting and the commercialization of publicly funded research. In Part I, I review the history of the search for the $B R C A$ genes, the background of gene patenting in the United States, ${ }^{12}$ as well as the judicial decisions in the Myriad case. In Part II, I analyze the Supreme Court's opinion in the case and explore its implications for science and biotechnology. I also situate the case in the broader context of university research and the healthcare system. I conclude with observations about the manner in which cases like Myriad exemplify the evolution of the common law, particularly in areas of rapid technological change.

\section{Cancer, Genes, and the Genetic Diagnostics Business}

At its heart, Myriad was decided on a narrow and arguably obscure question in patent law: whether human DNA sequences qualify as "inventions" under Section 101 of the Patent Act, ${ }^{13}$ or if they are instead ineligible for patent protection under the judicially-created "product of nature" doctrine. Why, then, did the case capture national media attention, draw demonstrators to the steps of the Supreme Court and invoke strong emotional responses on both sides of the issue? This Part reviews the history and background of the dispute that led to the Myriad case.

\section{A. The Long Road to BRCA}

Although medical professionals since the $19^{\text {th }}$ century suspected that there was a hereditary link to certain forms of cancer, it was not until the late $20^{\text {th }}$ century that advances in technology enabled the systematic study of

wins-39160 (quoting Mary Clair King: "I am delighted. This is a fabulous result for patients, physicians, scientists and common sense"); ACMG Applauds Supreme Court Decision on Gene Patents, Am. COll. Med. Genetics AND Genomics (Jun. 13, 2013), https://www.acmg.net//docs/GenePatientsDecision.pdf ("This is a thrilling victory for patients").

12. The story of $B R C A$, gene patenting, and Myriad Genetics is an international one, with significant developments occurring not only in the United States, but also in the United Kingdom, France, Canada, Australia, and Japan. This article focuses on the U.S. case. For a discussion of the landscape and debate outside the United States, see generally SHOBITA Parthasarathy, Building Genetic Medicine: Breast Cancer, Technology, And The Comparative Politics Of Health Care (2007); E. Richard Gold \& Julia Carbone, Myriad Genetics: In the Eye of the Policy Storm, 12 GENETICS MED. S39, S40 (2010); Robert Dalpé et al., Watching the Race to Find the Breast Cancer Genes, 28 SCI. TECH. \& HuM. VALUES 187, 204 tbl.3 (2003).

13. 35 U.S.C. $\S 101(2012)$. 
genetic factors affecting human health. ${ }^{14}$ Using new gene sequencing tools, researchers in the late 1980s identified genes associated with a handful of specific diseases such as cystic fibrosis and Huntington's Disease. ${ }^{15}$ Even then, the hunt for individual genes spread along the vast human genome remained a slow and painstaking process, often taking years to complete. Among the most elusive and most sought after of these genes were those related to cancer.

The dramatic race to sequence the $B R C A$ genes associated with breast and ovarian cancer has been the subject of popular books, ${ }^{16}$ academic articles, ${ }^{17}$ television documentaries, ${ }^{18}$ a feature film, ${ }^{19}$ and hundreds of media stories. ${ }^{20}$ During the last half of the $20^{\text {th }}$ century, finding the gene(s) associated with cancer established itself as one of the most challenging ambitions of genetic medicine.

One of the first researchers to focus on the genetics of breast cancer was Mary-Claire King at the University of California, Berkeley. ${ }^{21}$ King's team at Berkeley interviewed nearly 1,600 women in the San Francisco and Detroit metropolitan areas, collecting information about their family histories of breast cancer. ${ }^{22}$ She then used a computer program to estimate the influence that factors like the environment, age and genetics would have on incidence of the disease. King's team published their surprising results in $1988 .^{23}$

Contrary to prevailing scientific wisdom, which held that a complex disease like cancer had to be caused by the interaction of multiple genes, King's model predicted that a defect in a single, malicious gene carried by about 1 in 800 U.S. women was highly correlated with breast cancer in approximately $4 \%$ of families. Controlling for environmental and other factors, King calculated that women with this mutation had an $82 \%$ chance of contracting breast cancer by age 70 , in contrast to those in the general popu-

14. See, e.g., James D. WATSON With ANDreW Berry, DNA: The SeCret of LIFE 307-11 (2003).

15. See id.

16. See, e.g., Kevin Davies \& Michael White, Breakthrough: The Race to Find the Breast CANCER Gene (1996); Michael Waldholz, Curing CANCER: The STORY OF THE MEN AND WOMEN UNLOCKING THE SECRETS OF OUR DEADliest ILLNESS (1997); PARTHASARATHY, supra note 12.

17. See, e.g., Gold \& Carbone, supra note 12; Mary-Claire King, "The Race" to Clone BRCA1, 343 SCIENCE 1462, 1462 (2014).

18. See, e.g., 60 Minutes: Patented Genes (CBS television broadcast Apr. 4, 2010).

19. See, e.g., Decoding AnNie PARKer (Ozymandias Productions et al. 2013).

20. See Timothy Caulfield et al., Myriad and the Mass Media: The Covering of a Gene Patent Controversy, 9 Genetics IN MED. 850 (2007).

21. See King, supra note 17, at 1462.

22. Id.; DAVIES \& WHITE, supra note 16, at 92-94.

23. Beth Newman et al., Inheritance of Human Breast Cancer: Evidence for Autosomal Dominant Transmission in High-Risk Families, 85 ProC. NAT'L. ACAD. SCI. U.S.A. 3044 (1988). 
lation, whose risk was approximately $8 \%$-a whopping tenfold increase in risk. $^{24}$

At this point, the gene, which would become known as BRCAl (for Breast Cancer or, maybe, for Berkeley, California), was purely hypothetical-predicted by King's computer model but not verified in nature. To search for the gene itself, King's group collected family histories and DNA samples from hundreds of individuals across North America, South America and the United Kingdom. ${ }^{25}$ Then in August 1990, seventeen years after King began her search, her team found a promising genetic marker that was present in seven families in which the average age of breast cancer onset was under 45 . The odds that they had located the gene responsible for cancer in these families was a million to one in their favor. ${ }^{26}$ The marker lay on the long arm of chromosome 17 in a region about 22 million base pairs long. ${ }^{27}$ Not only had King's team proved that the BRCAl gene existed, but they had also dramatically narrowed the gene's location along the 3.2 billion base expanse of the human genome. ${ }^{28}$ King's discovery sparked a furious race among a dozen different research groups around the world. ${ }^{29}$ Each of them sought to become the first to identify and isolate the $B R C A 1$ gene.

24. Id. According to more recent estimates, approximately $12 \%$ of women in the general population will develop breast cancer sometime during their lives while $72 \%$ of women with a known BRCA1 mutation will develop breast cancer by age 80. BRCA1 and BRCA2: Cancer Risk and Genetic Testing, NAT'L CANCER INST., http://www.cancer.gov/cancertopics /factsheet/Risk/BRCA (visited Jun. 13, 2020).

25. DAVIES \& WHITE, supra note 16 , at 94.

26. In statistical terms, the marker, D17S74, had a logarithm-of-the-odds (LOD) score of 5.98 (approximately $1,000,000$ to 1 ) in favor of being linked to a cancer-related gene. Generally, an LOD score of 3 or higher (1,000 to 1 ) is considered strong evidence of linkage. See DAVIES \& WHITE, supra note 16, at 96.

27. King, supra note 17, at 1463; Jeff M. Hall et al., Linkage of Early-Onset Familial Breast Cancer to Chromosome 17q21, 250 SCIENCE 1684, 1684 (1990).

28. King, supra note 17, at 1463.

29. Id.; DAVIES \& WhITE, supra note 16. 


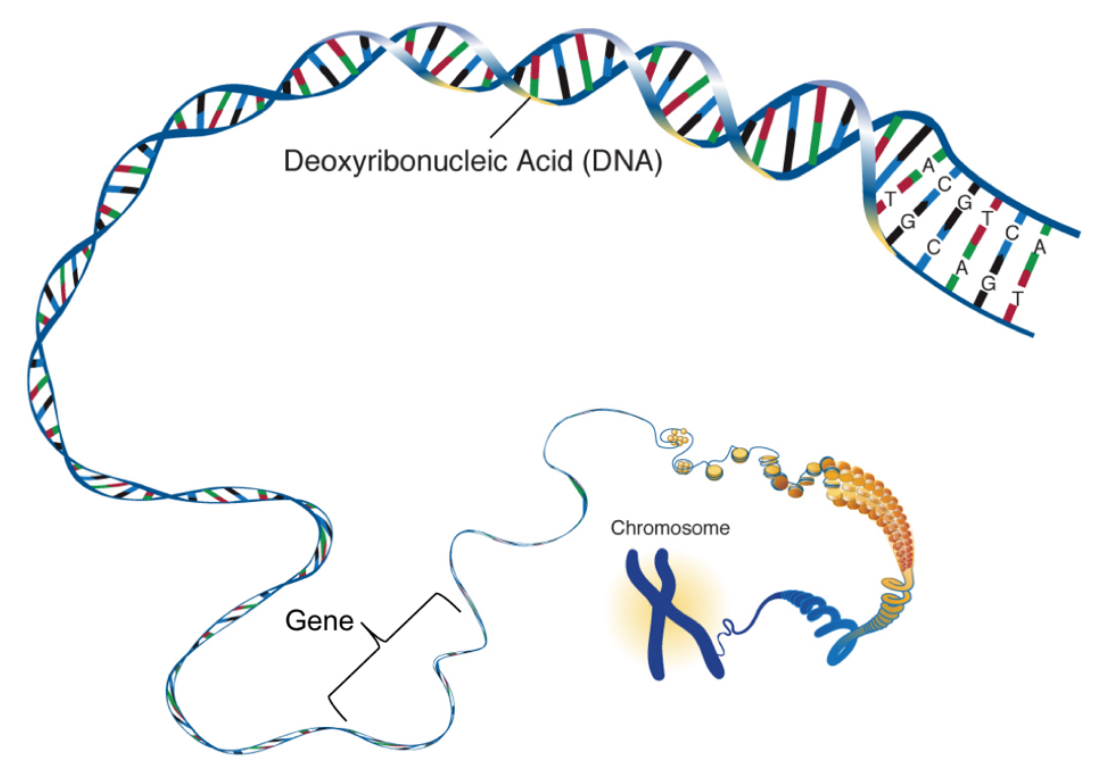

FIGURE I

Chromosomes, Genes, DNA and Nucleotide Base Pairs

(Source: National Human Genome Research Institute, ADAPTED BY THE AUTHOR)

Mark Skolnick at the University of Utah had long been interested in breast cancer genetics, building on the early work of Eldon Gardner and taking advantage of the vast collection of Mormon genealogical records in the state. ${ }^{30}$ A few months after King's announcement, Skolnick formed a private company, Myriad Genetics, with local investor Peter Meldrum and Nobel laureate and former CEO of Biogen Walter Gilbert. The company's goal was to build a genetic testing business based on the sequence of BRCAI gene, which it hoped to discover before any of the academic groups that had joined the hunt. Myriad raised more than $\$ 120$ million in venture capital funding between 1992 and $1994 .^{31}$ It also received financial support from pharmaceutical giant Eli Lilly \& Co., developer of the blockbuster antidepressant drug Prozac. Lilly paid \$2.8 million for a combination of Myriad stock and the exclusive right to commercialize Myriad's discoveries in the

30. The Church of Jesus Christ of Latter-Day Saints, also known as the Mormon Church, based in Salt Lake City, Utah, has kept detailed genealogical records of its members since 1894. By the early 1970s, church records contained genealogies of more than one million members. DAVIES \& WHITE, supra note 16.

31. Ass'n for Molecular Pathology v. U.S. Patent \& Trademark Office, 702 F. Supp. 2d 181, 201 (S.D.N.Y. 2010) [hereinafter Myriad 1]. 
area of breast cancer therapeutics. ${ }^{32}$ Finally, Myriad obtained an exclusive license to commercialize all breast cancer related discoveries made by Skolnick's university laboratory. In exchange, the University received 2\% of Myriad's stock as well as an up-front fee of $\$ 250,000$ and a $1 \%$ share of any future income that Myriad earned from its breast cancer discoveries. ${ }^{33}$

The race to find $B R C A 1$ was long and difficult, with numerous false leads and dead ends. By the summer of 1994, Myriad, together with a handful of collaborators, successfully isolated and sequenced the BRCA1 gene. ${ }^{34}$ It was the first to do so, and Myriad immediately filed a patent application covering the DNA sequence of the gene and several of its variants. ${ }^{35} \mathrm{~A}$ group of authors from Myriad and its collaborators published these results in the journal Science that October. ${ }^{36}$ A front page story in the New York Times announced that Myriad had won "a genetic trophy so ferociously coveted and loudly heralded that it had taken on a near-mythic aura . ..."37

Myriad owed its victory to a number of advantages that it had over its competitors. The first was access to the rich genealogical resources of Utah, including one sprawling family with twenty-five recorded cases of breast cancer over six generations. ${ }^{38}$ Another advantage was the relatively new and untested cloning technique that Myriad used, which proved to be particularly well-suited to the complex structure of the BRCA1 gene. ${ }^{39}$ Myriad also benefitted from access to high-throughput sequencing equipment acquired by its partner Eli Lilly.

32. While Myriad hoped to launch a genetic diagnostics business based on the BRCA genes, it knew that the "real" money was in therapeutics. For this reason, large pharmaceutical firms like Lilly were willing to pay Myriad for the exclusive right to exploit the genes that it discovered for therapeutic purposes, while leaving the diagnostics business to Myriad.

33. Exclusive License Agreement between Helix Technologies, Inc. and University of Utah Research Foundation (Oct. 8, 1991) (on file with the author). Myriad was originally named Helix Technologies, Inc. It changed its name to Myriad Genetics, Inc. in 1993, when advised that the name Helix was not available as a trademark. Telephone Interview with Mark Skolnick (Apr. 16, 2019).

34. Myriad I, 702 F. Supp. 2d, at 201-02.

35. 17Q-Linked Breast and Ovarian Cancer Susceptibility Gene, U.S. Patent No. 5,747,282, at 63 (filed June 7, 1995) (claiming priority to an earlier patent on Aug. 12, 1994). Several of the early patents covering the $B R C A$ genes were assigned to the University of Utah Research Foundation (UURF) pursuant to the original License Agreement between Myriad and the UURF, Exclusive License Agreement, supra note 33, and several later patents were jointly owned by Myriad, the UURF and other institutions. But because Myriad was the exclusive licensee of these patents and controlled their prosecution and enforcement, I refer to the patents throughout as "Myriad's" patents.

36. Yoshio Miki et al., A Strong Candidate for the Breast and Ovarian Cancer Susceptibility Gene BRCA1, 266 SCIENCE 66, 66 (1994).

37. Natalie Angier, Scientists Identify a Mutant Gene Tied to Hereditary Breast Can$c e r$, N.Y. TIMES, Sept. 15, 1994, at A1.

38. DAVIES \& WhITE, supra note 16, at 208.

39. See King, supra note 17, at 1462; J. Craig Venter et al., A New Strategy for Genome Sequencing, 381 NATURE 364, 364 (1996) (outlining Myriad's sequencing techniques). 
The discovery of $B R C A 1$ did not complete the puzzle of inherited breast cancer or its even deadlier cousin, ovarian cancer. Based on epidemiological evidence, researchers strongly suspected that another gene, which they named BRCA2, must also be at work. In September 1994, Michael Stratton at the Institute for Cancer Research (ICR) in London, together with 30 other researchers (including some at University of Utah), theorized that BRCA2 must lie somewhere along human chromosome $13 .{ }^{40}$ When Stratton learned that Myriad intended to patent BRCA2 once it was identified, he abruptly ended his collaboration with the researchers in Utah. ${ }^{41}$

This rift spurred a second race: this time, to sequence $B R C A 2 .^{42}$ This race was shorter than the race for $B R C A 1$ - just fourteen months - but was equally dramatic. Much of the scientific community, indignant at Myriad's plan to patent the BRCA genes, allied themselves with Stratton. The competing labs in Utah and London, together with their allies around the world, worked feverishly to complete the $B R C A 2$ sequence. For the first time, they did so by using data generated by the new Human Genome Project. The $B R C A 2$ race ended in a photo finish, as Stratton and Skolnick teams announced that they had isolated the gene within one day of each other. ${ }^{43}$ Stratton's group published its results in Nature on December 21, $1995,{ }^{44}$ and filed a patent application in the United Kingdom. ${ }^{45}$ But in the United States, the critical market for Myriad, Skolnick's team beat them to the punch. Myriad filed a patent application on December $18,{ }^{46}$ securing the U.S. rights to the $B R C A 2$ sequence for itself and the University of Utah.

\section{B. Gene Patenting in the United States}

The patentability of human DNA has been the subject of public controversy since at least the $1960 \mathrm{~s}$. But the pitch of the debate steadily rose through the late 1970s, reaching its height in the landmark 1980 Supreme Court case Diamond v. Chakrabarty ${ }^{47}$ In Chakrabarty, the Court established by a 5-4 majority that a living, genetically-modified organism (in this case a bacterium genetically modified to break down petrochemical products) was an invention eligible for patent protection. ${ }^{48}$ After Chakrabarty, the gene pa-

\footnotetext{
40. Richard Wooster et al., Localization of a Breast Cancer Susceptibility Gene, BRCA2, to Chromosome 13q12-13, 265 SCIENCE 2088, 2088 (1994).

41. See DAVIES \& WHITE, supra note 16, at 224-25.

42. See Myriad I, 702 F. Supp. 2d 181, 202.

43. Id. at 201.

44. Richard Wooster et al., Identification of the Breast Cancer Susceptibility Gene BRCA2, 378 NATURE 789 (1995).

45. U.K. Patent No. 2,307,477 (filed Nov. 25, 1996) (claiming priority to Nov. 23, 1995).

46. U.S. Patent No. 5,837,492 (filed Apr. 29, 1996) (claiming priority to Dec. 18, 1995).

47. 447 U.S. 303 (1980).

48. Id. at 317-18.
} 
tenting debate intensified. Biotechnology firms began to file patent applications covering an increasing number of DNA-based inventions, and the Patent and Trademark Office (PTO) began to issue these patents in large numbers. $^{49}$

The controversy surrounding the patentability of genes soon found its way into plans for the Human Genome Project (HGP), a massive international effort to map the entire sequence of 3.2 billion DNA base pairs in the human genome. In 1988, the National Research Council and leading genetics researchers recommended that all human DNA sequences be placed in the public domain. ${ }^{50}$ Representatives of the biotech industry, however, argued that patents on genes should be encouraged because they could foster new businesses and fuel the discovery of drugs and diagnostic tests. ${ }^{51}$

One of the most vocal supporters of gene patenting was J. Craig Venter, a researcher at the National Institutes of Health (NIH) who began to file patent applications covering short DNA segments known as "expressed sequence tags" (ESTs) in $1991 .^{52} \mathrm{NIH}$ 's decision to pursue these patents was criticized by many in the scientific community, including James Watson, the co-discoverer of the chemical structure of DNA and the U.S. director of the Human Genome Project. ${ }^{53}$ Even NIH's own advisory committees were "unanimous in deploring the decision to seek such patents." ${ }^{54}$ Criticisms like

49. See, e.g., Rebecca S. Eisenberg, Patenting the Human Genome, 39 EMORY L.J. 721, 721 n.4 (1990) (listing several such patents issuing during the 1980s); Andrew W. Torrance, Gene Concepts, Gene Talk, and Gene Patents, 11 MinN. J.L. SCI. \& TECH. 157, 176-77 (2010) (describing the first patents on human genetic material issued during the late 1970 s and early 1980s).

50. Comm. on Mapping and Sequencing the Human Genome, Nat'L Rsch. Council, MAPPING AND SEQuenCing THE Human GeNOME 8 (1988); Comm. ON INTELL. Prop. RTS. In GeNOMiC AND PROtein Rsch. \& InNOVATION, \& COMM. ON SCI., TeCh. \& L. Pol'y AND Glob. AfFS., NAT'L RSCH. COUNCIL, REAPING THE BENEFITS OF GENOMIC AND Proteomic ReSEARCH 27 (Stephen A. Merrill \& Anne-Marie Mazza eds., 2006) [hereinafter NRC-Genomic and Proteomic Research] ("[T]he data must be in the public domain, and the redistribution of the data should remain free of royalties.") (internal quotation marks omitted) (quoting the NIH Ad Hoc Program Advisory Committee on Complex Genomes); FRANCIS S. Collins, The Language of Life: DNA AND the Revolution in Personalized Medicine 301 (2010); James D. Watson, The Human Genome Project: Past, Present, and Future, 248 SCIENCE 44, 48 (1990).

51. See, e.g., John J. Doll, The Patenting of DNA, 280 SCIENCE 689, 690 (1998); George Poste, The Case for Genomic Patenting, 378 NATURE 534, 535 (1995).

52. Venter believed that ESTs could help to locate genes more quickly and efficiently than sequencing the entire genome. See JAMES ShreEve, The GenOME WAR: How CRAIG Venter TRied to CAPTURE THE COde OF Life AND SAVE THE World $82-83$ (2004). Venter went on to found Celera Genomics, the company that raced the public HGP to complete the human genome sequence. See id. at 118.

53. See Christopher Anderson, US Patent Application Stirs up Gene Hunters, 353 NATURE 485, 485 (1991); Leslie Roberts, Genome Patent Fight Erupts, 254 SCIENCE 184, 184 (1991).

54. Robert Cook-Deegan, The Gene Wars: Science, Politics, AND the Human GENOME 317 (1994). 
these caused NIH to back down, and in 1994 the agency reversed course, effectively abandoning its EST patent applications. ${ }^{55}$ NIH's pivot away from DNA patents signaled a new period of openness in the world of genomics research.

In early 1996, just as the Human Genome Project was beginning to gather steam, fifty leaders of the international scientific effort met at the coral pink Hamilton Princess Hotel in Bermuda. There, they hammered out a set of rules for publicly releasing all DNA sequences generated by the massive project. In a world where scientific data was often hoarded for years and discoveries were jealously guarded until published in peerreviewed journals, the Bermuda Principles were received with differing degrees of acclaim and dismay around the world. They shaped attitudes and norms within the global research community and continue, even today, to define the standard for sharing scientific data. ${ }^{56}$

Despite such well-meaning efforts, the private sector remained unmoved. As DNA sequencing technology continued to improve, the number of gene patents only grew. By 2005, researchers at MIT concluded that nearly 20 percent of known human genes were patented. ${ }^{57}$ Most of these patents were being issued not to companies, but to research universities, including the University of Utah.

55. Christopher Anderson, NIH Drops Bid for Gene Patents, 263 SCIENCE 909, 909 (1994). One of NIH's justifications for abandoning its patent applications on DNA sequences with no known function was their lack of "utility", one of the requirements for patentability. See Nat'l. Human Genome Rsch. Inst., NHGRI Policy Regarding Intellectual Property of Human Genomic Sequence, Apr. 9, 1996 (“In NHGRI's opinion, raw human genomic DNA sequence, in the absence of additional demonstrated biological information, lacks demonstrated specific utility and therefore is an inappropriate material for patent filing."). See also Rebecca S. Eisenberg, Correspondence, The Promise and Perils of Strategic Publication to Create Prior Art: A Response to Professor Parchomovsky, 98 MiCH. L. REV. 2358, 2364 n.26 (2000) (quoting policy). This position was confirmed by in re Fisher, 421 F.3d 1365, 1366 (Fed. Cir. 2005)

56. See, e.g., Jorge L. Contreras, Bermuda's Legacy: Patents, Policy and the Design of the Genome Commons, 12 MINN. J.L. SCI. \& TECH. 61, 65 (2011); Katherine Maxson Jones et al., The Bermuda Triangle: The Pragmatics, Policies, and Principles for Data Sharing in the History of the Human Genome Project, 51 J. Hist. BIOLOGY 693, 698 (2018).

57. Kyle Jensen \& Fiona Murray, Intellectual Property Landscape of the Human Genome, 310 SCIENCE 239, 239 (2005). 
TABLE I ${ }^{58}$

Summary of Genetic Disease Susceptibility Tests and Patents (2008)

\begin{tabular}{|c|c|c|c|}
\hline Disease & Gene(s) & Patent Owner(s) & $\begin{array}{l}\text { Exclusive } \\
\text { Licensee }\end{array}$ \\
\hline Alzheimer's & $\begin{array}{l}\text { APOE, } \\
\text { PSEN1, } \\
\text { PSEN2, } \\
\text { APP }\end{array}$ & Duke U. & $\begin{array}{l}\text { Athena Di- } \\
\text { agnostics }\end{array}$ \\
\hline Canavan & ASPA & $\begin{array}{c}\text { Miami Children's } \\
\text { Hosp. }\end{array}$ & None \\
\hline Cystic fibrosis & CFTR & $\begin{array}{l}\text { U. Mich., } \\
\text { Hosp. Sick Chil- } \\
\text { dren, Johns Hop- } \\
\text { kins }\end{array}$ & None \\
\hline Breast cancer & $\begin{array}{l}\text { BRCA1, } \\
\text { BRCA2 }\end{array}$ & $\begin{array}{c}\text { U. Utah, NIH, } \\
\text { CHUQ, Cancer } \\
\text { Inst. (Tokyo), } \\
\text { U. Leiden, } \\
\text { Endo Recherche, } \\
\text { Hosp. for Sick } \\
\text { Children, } \\
\text { U. Penn. } \\
\text { U. Cal., CRCT } \\
\text { (U.K.), OncorMed }\end{array}$ & $\begin{array}{c}\text { Myriad Ge- } \\
\text { netics }\end{array}$ \\
\hline $\begin{array}{l}\text { FAP (colon can- } \\
\text { cer) }\end{array}$ & APC & $\begin{array}{c}\text { Johns Hopkins, } \\
\text { U. Utah }\end{array}$ & $\mathrm{n} / \mathrm{a}$ \\
\hline Hemochromatosis & HFE & $\begin{array}{l}\text { Bio-Rad Labs (by } \\
\text { succession) }\end{array}$ & $\mathrm{n} / \mathrm{a}$ \\
\hline Hearing loss & GJB2 & Institut Pasteur & $\begin{array}{l}\text { Athena Di- } \\
\text { agnostics }\end{array}$ \\
\hline $\begin{array}{c}\text { Huntington's } \\
\text { Disease }\end{array}$ & IT-15 & $\begin{array}{c}\text { Mass General } \\
\text { Hosp. }\end{array}$ & none \\
\hline
\end{tabular}

58. Data compiled by the author from SEC'Y'S ADVISORY COMM. ON GENETICS, Health \& Soc'Y, U.S. DeP'T OF Health \& Hum. SERVS., Gene Patents AND Licensing PRACTICES AND THEIR IMPACT ON PATIENTS ACCESS TO GENETIC TESTS (2010), https://osp.od.nih.gov/wp-content/uploads/2013/11/SACGHS_patents_report_2010.pdf [hereinafter SACGHS 2010]; Robert Cook-Deegan et al., Impact of Gene Patents and Licensing Practices on Access to Genetic Testing for Inherited Susceptibility to Cancer: Comparing Breast and Ovarian Cancers with Colon Cancers, 12 GeNETICS MED. S15-S38 (2010); Brandon Pierce et al., The Impact of Patents on the Development of Genome-Based Clinical Diagnostics: An Analysis of Case Studies, 11 GeneTiCs MED. 202, 203-04 (2009); Myriad Genetics, Inc., Annual Report (Form 10-K) (Sept. 29, 1997); NRC-Genomic and Proteomic Research, supra note 50, at 65-67. 


\begin{tabular}{|c|c|c|c|}
\hline Disease & Gene(s) & Patent Owner(s) & $\begin{array}{c}\text { Exclusive } \\
\text { Licensee }\end{array}$ \\
\hline $\begin{array}{c}\text { Long-QT } \\
\text { Syndrome }\end{array}$ & LQTx & $\begin{array}{c}\text { U. Utah, Genzyme } \\
\text { Corp., Yale U. }\end{array}$ & PGxHealth \\
\hline Lynch syndrome & $\begin{array}{c}\text { MLH1, } \\
\text { MSH2 }\end{array}$ & $\begin{array}{c}\text { Or. Health Sci. U., } \\
\text { Dana Farber, } \\
\text { Johns Hopkins }\end{array}$ & None \\
\hline Melanoma & MTSx & Myriad Genetics & $\begin{array}{c}\text { Myriad Ge- } \\
\text { netics }\end{array}$ \\
\hline Ovarian cancer & BRCA2 & $\begin{array}{c}\text { U. Utah, CRCT } \\
\text { (UK) }\end{array}$ & $\begin{array}{c}\text { Myriad Ge- } \\
\text { netics }\end{array}$ \\
\hline $\begin{array}{c}\text { Maturity-onset } \\
\text { diabetes of the } \\
\text { young (MODY) }\end{array}$ & $\begin{array}{c}\text { HNCK, } \\
\text { HNore }\end{array}$ & $\begin{array}{c}\text { U. Chicago } \\
\text { Athena Di- } \\
\text { agnostics }\end{array}$ \\
\hline $\begin{array}{c}\text { Spinocerebellar } \\
\text { ataxia }\end{array}$ & SCA & $\begin{array}{c}\text { Baylor Coll. Med., } \\
\text { U. Minn. }\end{array}$ & $\begin{array}{c}\text { Athena Di- } \\
\text { agnostics }\end{array}$ \\
\hline Tay-Sachs & HEXA & NIH & None \\
\hline
\end{tabular}

C. The Inception of Myriad: Bayh-Dole, University Patents, and the Cold Fusion Debacle

Thanks in part to the success of academic-government collaboration on the Manhattan Project during World War Two, the post-war federal government began pouring money into academic laboratories. ${ }^{60}$ The prevailing wisdom at the time was that this funding of basic research would help not only national defense but also the U.S. economy. But this academic funding didn't have the residual economic impact the government had hoped for. Although an increasing share of each year's Nobel prizes went to American scientists over the next few decades, relatively little academic research was finding its way into the commercial sector. Unlike Japan, where the government directly funded industrial research in fields like semiconductors and consumer electronics, U.S. academic research between the 1940s and the 1970 s seemed to have few commercial applications. The problem, many felt, was patents. Specifically, not enough patents.

In response, Senators Birch Bayh, a Democrat from Indiana, and Bob Dole, a Republican from Kansas introduced legislation to harness the power of the American research establishment to help the private industry. The re-

59. Ambry Diagnostics also offered MODY testing, though it is unclear whether it was authorized to do so by the patent holder. Pierce et al., supra note 58, at 204.

60. In 1953, federal non-defense R\&D funding was $\$ 2.3$ billion. By 1980 , it had reached $\$ 43$ billion. Historical Trends in Federal R\&D, By Function: Defense and Nondefense R\&D Outlays, 1953-2020, AM. ASS'N FOR THE ADVANCEMENT OF SCIENCE (2020), https://www.aaas.org/sites/default/files/2020-05/Function.xlsx. 
sulting Bayh-Dole Act of $1980^{61}$ provided that when a university or other federally-funded institution develops a new technology, the institution is entitled to patent it. Moreover, if the institution fails to patent the technology, it could lose those valuable rights. The Bayh-Dole Act effectively penalized universities for not patenting their inventions. The Bayh-Dole Act also provided that any institution earning revenue from one of these patents must share some of the profits with the individual inventors. The statute does not specify how much each inventor should receive, but most universities have developed a rough three-way split of these profits. ${ }^{62}$

This generous arrangement offers large potential rewards to entrepreneurial academics. A researcher could form a start-up company to commercialize the scientific discoveries made in his or her laboratory, the university would own the patents and then grant the start-up company exclusive rights to utilize those patents in return for a share of the revenue. External investors-venture capitalists and, at a later stage, investors in public marketswould provide the capital necessary to fund the commercial growth of the company.

The spinout company strategy was particularly attractive for the University of Utah. Unlike other academic institutions in Silicon Valley and the East Coast, the University of Utah's geographical isolation limited its opportunities to collaborate with local companies. So, if entrepreneurial university researchers wished to collaborate with a startup company, they had to form one themselves, usually with the University's help. As a result, the University of Utah quickly began to rival much larger research universities in terms of company formation. During the decade after the Bayh-Dole Act was passed, the University of Utah created sixty-two spinout companies, second in number only to MIT. ${ }^{63}$

Like many universities, the University of Utah established a Technology Transfer Office ("TTO") to obtain and manage patents on university research. By the mid-1980s, Utah's TTO was bustling. The University was enjoying a boom in biomedical engineering, sparked by the first artificial heart - the Jarvik-7 — which had been developed and implanted into a living patient's chest in $1982 .{ }^{64}$ By the mid-80s, projects were under way in Utah to develop artificial arms, hands, kidneys, bladders, fallopian tubes, and

61. Bayh-Dole Act, Pub. L. No. 96-517, 94 Stat. 3015 (codified as amended at 35 U.S.C. $\S \S 200-211)$. For an early history and analysis of the Bayh-Dole Act, see Rebecca Eisenberg, Public Research and Private Development: Patents and Technology Transfer in Government Sponsored Research, 82 VA. L. REV. 1663, 1691-95 (1996).

62. Jennifer Carter-Johnson, University Technology Transfer Structure and Intellectual Property Policies, in Research HANDBOOK ON InTELlectual Property AND TECHNOLOGY TRANSFER 4, 26-27 (Jacob H. Rooksby ed., 2020).

63. Rory P. O'Shea et al., Entrepreneurial Orientation, Technology Transfer and Spinoff Performance of U.S. Universities, 34 RES. POL'Y 994, 1002 (2005).

64. Univ. of Utah, How the West Won Medicine: From SMall Medical SCHOOL To Global ACADEMIC ForCE (2015). 
sphincters. ${ }^{65}$ One of the most significant aspects of the University's artificial organ program was its early outreach to the private industry, a move that some branded, not entirely kindly, as "academic capitalism." ${ }^{66}$ By 1986, Utah's TTO was earning roughly a million dollars per year from research funding and patent royalties. ${ }^{6}$

Then, in the summer of 1988, the University's research landscape was transformed again. The head of the chemistry department, a soft-spoken researcher named Stanley Pons, and Martin Fleischmann, a visiting researcher from England, thought they had stumbled onto the Holy Grail of energy research: sustained nuclear fusion at room temperature, also known as cold fusion. ${ }^{68}$ If cold fusion was achievable, the process would generate more energy than it consumed, which would have been a world-changing proposition. Of course, the university's dalliance with cold fusion didn't last longthe effects observed by Pons and Fleischman were likely attributable to nothing more than measurement errors that could not be replicated elsewhere. By 1991, after wasting two years and more than five million taxpayer dollars, the University of Utah shut down its cold fusion research institute and both the university President and head of the TTO resigned.

Badly bruised by the cold fusion debacle, the University of Utah sought more conventional technology startups. Later that year, when Mark Skolnick proposed the formation of Myriad, the University was pleased to offer him an exclusive license to whatever discoveries his University laboratory made at a relatively modest rate.

\section{Myriad's BRCA Patents}

Myriad began to seek patent protection for its $B R C A$-related discoveries years before it isolated the genes themselves. In 1992, it filed a patent application entitled "Mapping, Isolation and Characterization of a Cancer Susceptibility locus and allele on the Long Arm of Human Chromosome 17," based on techniques that it had developed to search for $B R C A 1 .{ }^{69}$ As the race to find $B R C A 1$ wore on, Myriad filed a series of amendments and continuations based on the original "chromosome 17" application, each time

65. Bill Curry, Utah University Spurs Creation of 'Bionic Valley': Artificial Body Parts May Aid Thousands, L.A. TIMES (Nov. 10, 1985, 12:00 AM), https://www.latimes.com /archives/la-xpm-1985-11-10-mn-3370-story.html.

66. Id.

67. Interview by Robert Miller with James J. Brophy, Vice President for Research, University of Utah, in Salt Lake City, Utah (Apr. 9, 1991).

68. The saga of the cold fusion debacle at the University of Utah is chronicled in GARY TAubes, BAD SCIENCE: The Short Life AND Weird Times of Cold Fusion (1993). See B. V. Lewenstein \& W. Baur, A Cold Fusion Chronology, 152 J. RADiOANALYTICAL \& NuCLEAR CHEMISTRY 273, 275-78 (1991).

69. U.S. patent application filed on March 26, 1992. This application never matured into an issued patent. 
adding new information that had been gleaned by the research team. ${ }^{70}$ Thus, even if Myriad did not win the scientific race to sequence $B R C A 1$, the chromosome 17 patent enabled it to mount a competitive BRCAl testing business. That is, so long as their patent covered something relevant to $B R C A 1$, they could use it as leverage to obtain a license from whoever received the patent on the actual $B R C A 1$ sequence. ${ }^{71}$

The patent application covering the correct location and sequence for BRCAl was filed on August 12, 1994. It was entitled "17q-linked Breast and Ovarian Cancer Susceptibility Gene." Over the years, that single application, like the patriarch of a great Mormon family, spawned numerous new applications - children, grandchildren, cousins - all claiming "priority" back to its original filing date. Legally speaking, August 12, 1994 is the date that the breast cancer gene BRCA1 was "invented."

The PTO began to issue Myriad's BRCA patents in 1997. In total, Myriad received thirteen patents covering different aspects of the $B R C A 1$ and $B R C A 2$ genes, including their DNA sequences, the sequences of smaller DNA segments contained within the genes, the principal variants associated with increased cancer risk, methods of locating the genes, and use of the genes as diagnostic tools and screens for the development of drugs. ${ }^{72}$

When searching for the $B R C A$ genes, researchers from Myriad and the University of Utah collaborated with colleagues from NIH, McGill University, and the Cancer Institute of Japan. Individuals from each of these institutions were thus listed as co-inventors on one or more of the $B R C A$ patents. $^{73}$ Eventually, through a series of private agreements, all of these institutions ceded control over the $B R C A$ patents to Myriad. ${ }^{74}$

70. Myriad filed continuation-in-part applications based on the March 1992 "chromosome 17" application in October 1992, February 1993 and August 1993. None of these applications matured into an issued patent.

71. As early as March 1993, Myriad's Scientific Advisory Board concluded that Myriad would "offer diagnostic services for BRCA1 regardless of discovery outcome as long as it appears that our patent is relevant." Myriad Genetics, Minutes of Scientific Advisory Board Meeting (Mar. 18-19, 1993) (on file with author).

72. U.S. Patent No. 5,693,473 (issued Dec. 2, 1997); U.S. Patent No. 5,709,999 (issued Jan. 20, 1998); U.S. Patent No. 5,710,001 (issued Jan. 20, 1998); U.S. Patent No. 5,747,282 (issued May 5, 1998); U.S. Patent No. 5,753,441 (issued May 19, 1998); U.S. Patent No. 5,837,492 (issued Nov. 17, 1998); U.S. Patent No. 6,033,857 (issued Mar. 7, 2000); U.S. Patent No. 6,124,104 (issued Sep. 26, 2000); U.S. Patent No. 6,162,897 (issued Dec. 19, 2000); U.S. Patent No. 7,250,497 (issued Jul. 31, 2007); U.S. Patent No. 7,993,835 (issued Aug. 9, 2011); U.S. Patent No. 8,476,020 (issued Jul. 2, 2013). Ironically, the last of these patents, claiming variants in the $B R C A 2$ gene useful as diagnostic biomarkers, was issued two weeks after the Supreme Court invalidated most of Myriad's challenged patent claims.

73. Two NIH researchers were initially omitted from the Myriad patent application and were only added as inventors after the NIH filed a competing patent application at the U.S. Patent and Trademark Office. The dispute was settled with agreement to add the NIH inventors to Myriad's patent. See Myriad I, 702 F. Supp. 2d 181, 201-02 (S.D.N.Y. 2010); Andrew A. Skolnick, Cancer Gene Patent Dispute Settled, 273 J. AM. MED. Ass’N 833, 833 (1995).

74. See PARTHASARATHY, supra note 12, at 116-17. 
Myriad and its collaborators were not the only ones to obtain patents covering the $B R C A$ genes. One U.S.-based company, OncorMed, Inc., succeeded in patenting a slightly different set of $B R C A$ sequences than Myriad. ${ }^{75}$ OncorMed's principal U.S. patent on $B R C A 1$ issued in 1997, slightly before Myriad's first patent. OncorMed also obtained exclusive rights to some of the early BRCA markers discovered by King's group at Berkeley and to the rights held by ICR in the UK. ${ }^{76}$ When it became clear that Myriad had no intention of striking a deal with OncorMed, OncorMed sued Myriad for patent infringement, ${ }^{77}$ and Myriad counter-sued shortly thereafter. ${ }^{78}$ Their lengthy litigation was eventually settled when Myriad acquired OncorMed's BRCA testing business and patent rights in $1998 .^{79}$ Thus, by the end of the 1990s, Myriad had consolidated control over substantially all U.S. patent rights in the $B R C A$ genes. ${ }^{80}$

\section{E. The Business of $\mathrm{BRCA}$}

Unlike some companies, Myriad did not acquire its patents for show. From its inception, Myriad's plan was to use patents to secure exclusivity in the market for $B R C A$ testing.

\section{Consolidation of the $B R C A$ Testing Market}

Soon after the sequences of the $B R C A$ genes were published in scientific literature, several U.S. laboratories began to test patients for $B R C A$ mutations. By the late 1990s, four significant $B R C A$ testing providers had emerged: Myriad, OncorMed, the Genetic Diagnostic Laboratory at the University of Pennsylvania (GDL), and the Genetics and IVF Institute (GIVF), a private clinic based in northern Virginia. ${ }^{81}$ Each of these entities developed a slightly different approach to BRCA testing, the most comprehensive (and expensive) of which was Myriad's. ${ }^{82}$

OncorMed's $B R C A$ testing program ended after Myriad acquired its assets in $1998 .^{83}$ In the same year, Myriad sent "cease and desist" letters to

\footnotetext{
75. U.S. Patent No. 5,654,155 (filed Aug. 5, 1997).

76. PARTHASARATHY, supra note 12 , at 74 .

77. Oncormed, Inc. v. Myriad Genetics, Inc., No. 1:97-cv-02722-JR (D.D.C. dismissed June 1, 1998).

78. Myriad Genetics, Inc. v. Oncormed, Inc., No. 2:97-cv-00922-DB (D. Utah dismissed June 4, 1998).

79. OncorMed, Inc., Quarterly Report (Form 10-Q) 11 (Aug. 8, 1998) (OncorMed reported gain of $\$ 525,000$ on the sale of its breast cancer testing service, including customer lists, databases, and other intangible assets).

80. See Cook-Deegan et al., supra note 58, at S20-21 tbl.2 (showing ownership and licensing status of all issued U.S. patents covering $B R C A 1 / 2$ genes).

81. PARTHASARATHY, supra note 12 , at $68-92$.

82. See id.

83. Myriad I, 702 F. Supp. 2d 181, 206 (S.D.N.Y. 2010).
} 
GIVF and the University of Pennsylvania, notifying them that their $B R C A$ testing programs infringed Myriad's patents. ${ }^{84}$ GIVF, not wishing to engage in litigation, promptly discontinued its $B R C A$ testing service. ${ }^{85}$

Haig Kazazian, the head of Penn's GDL, was less accommodating. Though Kazazian initially ignored Myriad's threats, ${ }^{86}$ once Myriad sued the University of Pennsylvania in November 1998, GDL also discontinued $B R C A$ testing. ${ }^{87}$

In addition to the University of Pennsylvania, Myriad allegedly notified other academic laboratories, including the Cancer Genetics Network Project, sponsored by the National Cancer Institute (NCI), New York University, Georgetown University, and the Yale DNA Diagnostics Lab, ${ }^{88}$ that its patents covered $B R C A$ testing services. After receiving these notices, each of these laboratories also discontinued its $B R C A$ testing services. According to one study, nine different U.S.-based laboratories stopped performing $B R C A$ testing as a result of Myriad's patent assertion campaign. ${ }^{89}$ As a result of these efforts, by the beginning of the $21^{\text {st }}$ century, Myriad had become the sole provider of $B R C A$ testing in the United States.

\section{BRACAnalysis - Cost and Coverage}

As the only $B R C A$ test provider in the United States, there were few competitive constraints on Myriad's pricing of its tests. Prior to the discontinuation of its $B R C A$ testing service, the GDL charged approximately $\$ 1,500$ per test. ${ }^{90}$ In contrast, by 2008 , the cost of Myriad's BRACAnalysis test was approximately $\$ 3,120,{ }^{91}$ substantially more than it charged for other genetic tests, as to which it did not have a controlling patent position. ${ }^{92}$

One of the key factors in selling any medical product or service in the United States is how, and to what degree, it will be covered by the healthcare payment system. This complex system involves private medical

\footnotetext{
84. Id. at 205.

85. PARTHASARATHY, supra note 12 , at 117.

86. See Declaration of Haig H. Kazazian, Jr., M.D. at 3-4, Myriad I, 702 F. Supp. 2d 181 (No. 09-4515).

87. Myriad Genetics, Inc. v. Univ. of Pa., No. 2:98-cv-00829 (D. Utah dismissed Apr. 20, 1999).

88. Declaration of Arupa Ganguly at 1-2, 5-7, Myriad I, 702 F. Supp. 2d 181 (No. 094515); Declaration of Ellen T. Matloff at 1, 3-4, Myriad I, 702 F. Supp. 2d 181 (No. 094515).

89. Mildred K. Cho et al., Effects of Patents and Licenses on the Provision of Clinical Genetic Testing Services, 5 J. MoleCUlAR Diagnostics 3, 5-6 tbl.2 (2003).

90. PARTHASARATHY, supra note 12 , at 70.

91. Cook-Deegan et al., supra note 58, at S17.

92. In 2008, Myriad charged $\$ 1,795$ for familial adenomatous polyposis (FAP), a field in which Myriad had four competing labs charging between $\$ 1,200$ and $\$ 1,675$, and $\$ 2,950$ for hereditary non-polyposis colorectal cancer (HNPCC), a field in which Myriad had six competitor labs charging between $\$ 1,800$ and $\$ 4,646$. Id . at S17, S24.
} 
insurers, health management organizations, and three major governmental reimbursement programs (Medicare, Medicaid, and the Veteran's Administration). Importantly, coverage for genetic testing has long been uncertain and contested. Like any new technology, healthcare payors must develop criteria to determine which genetic tests, if any, they will cover.

From the payor's standpoint, this determination is largely actuarial. At one end of the coverage spectrum, a payor could cover $B R C A$ testing for everyone, which would detect the largest number of at-risk individuals, but would likely be cost prohibitive. At the other end of the spectrum, a payor could cover no $B R C A$ testing, meaning that even high-risk individuals would lack key information in deciding whether to undergo cost-saving prophylactic procedures before contracting cancer (e.g., prophylactic mastectomy or chemotherapy), also increasing the payor's cost. Thus, from a cost-effectiveness standpoint, the payor would ideally cover testing for enough individuals who are likely to contract the disease that the cost savings from avoiding disease treatment would outweigh the total cost of testing plus prophylactic procedures for those who tested positive.

Myriad began to approach insurers regarding coverage of $B R C A$ tests soon after releasing BRACAnalysis in 1996. According to Myriad, by 1999 nearly 400 private insurers, including Kaiser Permanente, Aetna U.S. Health Care, and Blue Cross Blue Shield, covered Myriad's test. ${ }^{93}$ And by 2009, Myriad could report that 90 percent of the tests that it performed were covered by insurance. ${ }^{94}$

Nevertheless, by 2010, twenty-five state Medicaid providers had still not approved BRACAnalysis for coverage at the rates charged by Myriad, and the company was unwilling to reduce its prices. ${ }^{95}$ Moreover, some payors that covered $B R C A$ testing did so only for those patients with family histories of breast cancer or who were members of known "high risk" groups such as those with Ashkenazi Jewish ancestry. Even when payors did cover testing, not all plans covered the full range of Myriad's tests. ${ }^{96}$

In response to some of these issues, as well as negative publicity being generated about the company, Myriad created a financial assistance program to help low-income and uninsured individuals obtain $B R C A$ testing. ${ }^{97}$ While this program enabled additional individuals to be tested, there re-

\footnotetext{
93. Declaration of Gregory C. Critchfield at 15, Myriad I, 702 F. Supp. 2d 181 (No. 094515).

94. Id. at 15-16. These statistics, of course, do not take into account individuals who were never tested because testing was not covered by their insurance providers or because they were uninsured.

95. See id. at 16; Declaration of Todd Ogaard at 2-3, Myriad I, 702 F. Supp. 2d 181 (No. 09-4515); Declaration of William E. Rusconi at 2-3, Myriad I, 702 F. Supp. 2d 181 (No. 09-4515).

96. See Complaint at 27-28, Myriad I, 702 F. Supp. 2d 181 (No. 09-4515).

97. Declaration of Gregory C. Critchfield, supra note 93, at 16; Declaration of Todd Ogaard, supra note 95, at 2-3; Declaration of William E. Rusconi, supra note 95, at 2-3.
} 
mained many individuals who had been recommended testing but could still not afford it. ${ }^{98}$ This situation led to substantial public criticism of Myriad's business practices and, indirectly, the patents that enabled it to maintain its exclusive market in BRCA testing. ${ }^{99}$

\section{AMP v. Myriad-THE Litigation}

\section{A. Southern District of New York}

In May 2009, the American Civil Liberties Union (ACLU) and the Public Patent Foundation (PubPat) filed a declaratory judgment action in the U.S. District Court for the Southern District of New York seeking to invalidate fifteen claims of seven different $B R C A$-related patents held by Myriad and the University of Utah. ${ }^{100}$ The twenty named plaintiffs in the case included medical and scientific societies, ${ }^{101}$ individual researchers, physicians and genetic counselors, individuals at risk of breast or ovarian cancer who were unable to obtain some or all $B R C A$ testing, and advocacy groups seeking to advance women's health and cancer prevention. Each of these plaintiffs alleged harm from the existence and assertion of the $B R C A$ patents. ${ }^{102}$

Senior District Judge Robert W. Sweet granted summary judgment for the plaintiffs on April 2, 2010, holding that all fifteen of Myriad's challenged patent were invalid as directed to ineligible subject matter under Section 101 of the Patent Act. With respect to Myriad's "composition of matter" claims covering the sequence of the isolated $B R C A$ genes and their known cancer-associated variants, he held that "[i]n light of DNA's unique qualities as a physical embodiment of information, none of the structural and functional differences cited by Myriad... render the claimed DNA

98. Myriad I, 702 F. Supp. 2d at 204; see also Gale Scott, Test That Saved Angelina Not Widely Covered, CRAIN's N.Y. Bus. (May 15, 2013, 12:00 AM), https://www.crainsnewyork.com/article/20130515/HEALTH_CARE/130519928/genetic-testfor-cancer-risk-that-saved-angelina-jolie-not-widely-covered (noting that "[t]he problem is that unless patients already have cancer, or have a family history where breast or ovarian cancer struck many relatives, particularly at a young age, insurance will not cover the more than $\$ 3,000$ test").

99. See generally A. Lane Baldwin \& Robert Cook-Deegan, Constructing Narratives of Heroism and Villainy: Case Study of Myriad's BRACAnalysis ${ }^{\circledR}$ Compared to Genentech's Herceptin ${ }^{\circledR}, 5$ GENOME MED. 1 (2013) (observing the "villainization" of Myriad on account of its restrictive licensing practices and high pricing).

100. For a first-hand account of the Myriad litigation, as told by one of the ACLU attorneys involved in the case, see Sandra S. Park, Gene Patents and the Public Interest: Litigating Association for Molecular Pathology v. Myriad Genetics and Lessons Moving Forward, 15 N.C. J.L. \& TECH. 519 (2014).

101. One of these was the Association for Molecular Pathology, a Maryland-based trade association serving the genetic diagnostics industry. As the first plaintiff in alphabetical order, its name will forever be associated with the Myriad case.

102. See Myriad I, 702 F. Supp. 2d. at 189-92. 
'markedly different"' than naturally-occurring DNA. ${ }^{103}$ In response to Myriad's claims covering methods "for diagnosing a predisposition for breast cancer in a human subject" ${ }^{104}$ by comparing a patient's $B R C A$ gene to the sequence of known $B R C A$ mutations, Judge Sweet held that such comparisons were "mental processes[] and abstract intellectual concepts" 105 that were also ineligible for patent protection under the Supreme Court's recent decision in Bilski v. Kappos. ${ }^{106}$ Finally, regarding one claim covering "[a] method for identifying potential cancer therapeutics" by observing the effect of a drug candidate on cancer cells containing mutated $B R C A$ genes, Judge Sweet held that the claimed process was nothing more than "the scientific method itself" and thus ineligible subject matter for patent protection. ${ }^{107}$

\section{B. Court of Appeals for the Federal Circuit}

Myriad appealed to the Court of Appeals for the Federal Circuit, the exclusive U.S. appellate venue for patent cases. The case was heard by a three-judge panel consisting of Circuit Judges Alan Lourie, Kimberly Moore, and William Bryson. On July 29, 2011, the Federal Circuit issued an opinion authored by Judge Lourie.

First, Myriad challenged the standing of the plaintiffs to contest its patents under the Declaratory Judgment Act. ${ }^{108}$ It argued that none of the plaintiffs had a sufficiently immediate and concrete apprehension of suit to maintain an action under the Declaratory Judgment Act. The Federal Circuit unanimously agreed with Myriad that nineteen of the twenty plaintiffs did not have standing. However, they also held that Dr. Harry Ostrer of NYU Medical Center, who declared that he would immediately commence $B R C A$ testing if Myriad's patents were invalidated, had standing to challenge the patents in federal court. ${ }^{109}$

With Dr. Ostrer adjudged to have standing, the Federal Circuit next addressed the substantive evaluation of Myriad's claims. The Federal Circuit panel unanimously affirmed the District Court's rejection of Myriad's diagnostic method claims, finding them to be directed to "abstract mental processes" and thereby ineligible for patent protection under the Supreme Court's precedent in Bilski. ${ }^{110}$ However, the Federal Circuit unanimously reversed the District Court with respect to Myriad's therapeutic screening

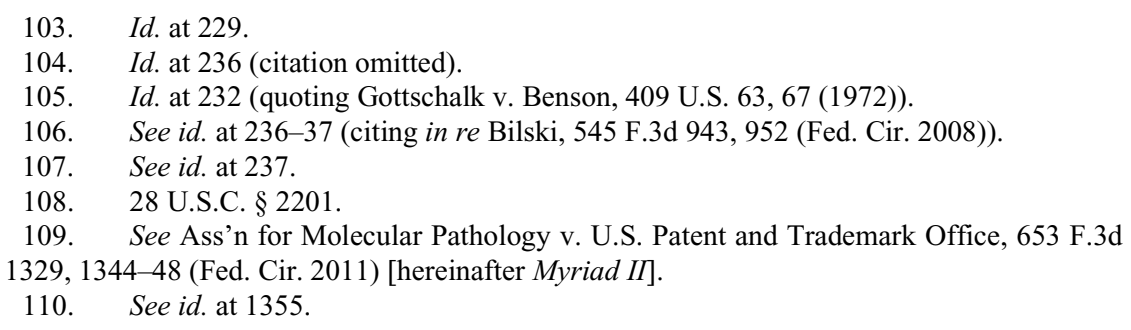


claim, holding that it included sufficiently "transformative steps," rendering it patent-eligible under Bilski. ${ }^{11}$

The judges of the Federal Circuit panel did not agree, however, on the treatment of Myriad's composition of matter claims, which the District Court had rejected. Writing for the majority, Judge Lourie explained that the $B R C A$ genes, when isolated and extracted from the cellular nucleus, were chemically and structurally distinct from any DNA found in the human body. He emphasized that the nucleotides in a DNA molecule are not simply the letters A, C, T and G, as they are commonly represented, but complex organic chemical structures. As such, when extracted from the chromosomes on which they typically reside, they are chemically different from the genes within the chromosome. Accordingly, such isolated and purified genes would constitute man-made products of "human ingenuity" and thus eligible for patent protection under the Supreme Court's precedent in Chakrabarty. ${ }^{12}$

\section{ACGTATTCGAA Isolated Gene}

FIGURE 2A

A Geneticist's View of Genes, Showing DNA Nucleotides as One of Four Letters A, C, G or T (adopted by Judge Sweet at the District Court) (Source: The Author)

111. See id. at 1357 (quoting Research Corp. Techs., Inc. v. Microsoft Corp., 627 F.3d 859, 868-69 (Fed. Cir. 2010)).

112. See id. at 1351-52 (quoting Diamond v. Chakrabarty, 447 U.S. 303 (1980)). 


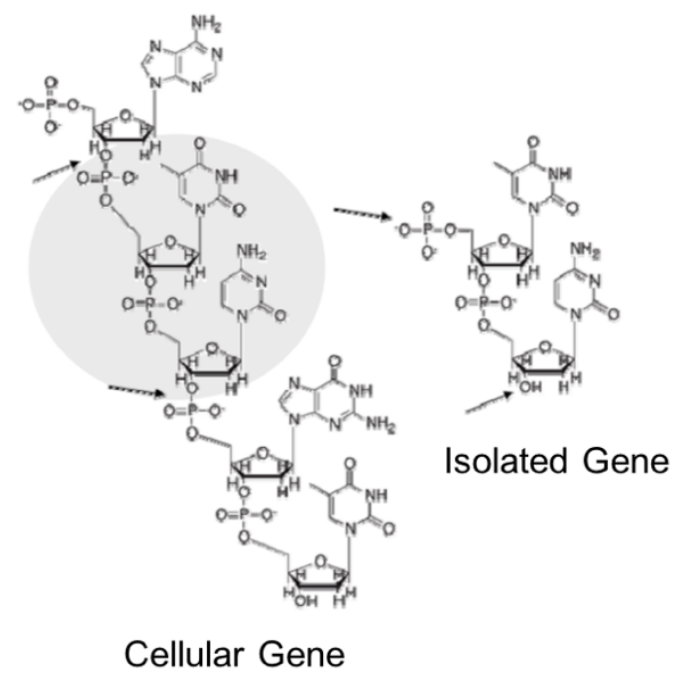

FIGURE 2B

A Chemist's View of Genes, Showing the Chemical Structure of Each Nucleotide (Adopted by Judge Lourie at the Federal

Circuit) (SOURCE: Myriad II, 653 F.3D AT I362)

Judge Moore concurred in this part of the holding but wrote separately to emphasize both the longstanding PTO practice of granting patents on isolated human genes, as well as the potential economic fallout that could result from a reversal of this longstanding practice. ${ }^{113}$

Judge Bryson, however, dissented from this portion of the court's opinion. He reasoned that Myriad was merely one of many researcher groups working to identify the $B R C A$ sequence, that Myriad did not make the most significant breakthrough (i.e., King's location of the gene on chromosome 17), and that it used known (i.e., non-innovative) techniques to sequence the $B R C A$ genes. Taken together, Judge Bryson concluded that Myriad's discovery of the sequence for the $B R C A$ genes was not an "invention" that was eligible for patent protection. ${ }^{114}$

In view of this result, the plaintiffs filed a petition for certiorari to the Supreme Court. ${ }^{115}$ However, in March 2012 the Supreme Court decided

113. Myriad II, 653 F.3d at 1367, 1368 (Moore, J., concurring).

114. Myriad II, 653 F.3d at 1373 (Bryson, J., dissenting).

115. Petition for Writ of Certiorari at 25, 31, Ass'n for Molecular Pathology v. Myriad Genetics, Inc., 566 U.S. 902 (2011) (No. 11-725). Myriad did not seek certiorari of the Federal Circuit's rejection of its method claims. 
Mayo Collaborative Services v. Prometheus Laboratories, Inc., ${ }^{116}$ a case limiting the patentability of diagnostic methods under Section 101 of the Patent Act. The Supreme Court then granted certiorari in Myriad, vacated the Federal Circuit's 2011 decision, and remanded the case to the Federal Circuit for reconsideration in light of Mayo $^{117}$ (a judicial maneuver referred to as GVR - "grant, vacate, remand"). The Federal Circuit reheard argument in Myriad and issued a new opinion on August 16, 2012, largely restating its 2011 decision. ${ }^{118}$

\section{The Supreme Court}

In late 2012, the plaintiffs filed a new petition for certiorari. ${ }^{119}$ The Supreme Court granted the petition, but only as to a single question: "Are human genes patentable?",120

Once it was on a clear path to the Supreme Court, the Myriad case attracted significant attention. News reports ran in national print and television outlets. Members of the public camped outside the Court overnight, hoping to get a seat at the oral argument. Demonstrators waving colorful banners stood in front of the Court on the rainy April day that oral arguments were held. ${ }^{121}$

Then, just a few weeks after the oral arguments, actress Angelina Jolie announced in a New York Times op-ed that she carried a deleterious $B R C A$ mutation, and that as a result she had undergone a prophylactic bilateral mastectomy. ${ }^{122}$ Jolie's announcement, in which she noted the issues raised by Myriad's patents, underscored the importance of the case in the public eye and perhaps to the Court as well.

The Court's unanimous decision, largely reversing the Federal Circuit, was issued on June 13, 2013. ${ }^{123}$ Justice Thomas, writing for the Court, began by explaining that Myriad's discovery of the BRCA genes - even if it involved substantial time, expense, and skill - was not "an act of inven-

116. Mayo Collaborative Servs. v. Prometheus Labs., Inc., 566 U.S. 66 (2012).

117. Ass'n for Molecular Pathology v. Myriad Genetics, Inc., 556 U.S. 902 (2012) (mem.).

118. Ass'n for Molecular Pathology v. U.S. Patent and Trademark Office, 689 F.3d 1303, 1303-04 (Fed. Cir. 2012).

119. Petition for Writ of Certiorari, Ass'n for Molecular Pathology v. Myriad Genetics, Inc., 689 F.3d 1303 (Fed Cir. 2012) (No. 12-398).

120. Ass'n for Molecular Pathology v. Myriad Genetics, Inc., 568 U.S. 1045 (2012) (mem.).

121. See, e.g., Erika Check Hayden, Cancer-Gene Data Sharing Boosted, 510 NATURE 198, 198 (2014).

122. Angelina Jolie, Opinion, My Medical Choice, N.Y. TIMES (May 14, 2013), https://www.nytimes.com/2013/05/14/opinion/my-medical-choice.html.

123. Ass'n for Molecular Pathology v. Myriad Genetics, Inc., 569 U.S. 576, 577-78 (2013) [hereinafter Myriad IV]. 
tion." ${ }^{124}$ Like Judge Sweet, he minimized the importance of Myriad's technical contribution: "Before Myriad's discovery of the BRCA1 and BRCA2 genes, scientists knew that heredity played a role in establishing a woman's risk of developing breast and ovarian cancer." ${ }^{125} \mathrm{He}$ also stressed that Myriad merely identified the "exact" or "precise" location and sequence of the $B R C A$ genes, ${ }^{126}$ reducing Myriad's contribution, from a major discovery to a mere refinement of existing knowledge, akin to adding another number behind the decimal point. He concluded by declaring that "Myriad did not create anything." 127

Given this lead-in, it is not surprising that the Court rejected Myriad's composition of matter claims. They cover unpatentable "products of nature" and thus fail to meet the statutory requirements for patent eligibility. With this said, the Court then tosses Myriad an olive branch. Justice Thomas noted that complementary (cDNA), artificially-synthesized nucleotide sequences that contain only the coding regions of the gene, do not occur naturally, and thus are eligible for patent protection. ${ }^{128}$ In advancing this comcompromise position, Justice Thomas largely adopted the arguments made by the Solicitor General, who appeared as amicus curiae in the case. ${ }^{129}$

Justice Scalia concurred in the Court's judgment, but wrote a short, quixotic concurrence in which he noted that he expressed no view regarding the "fine details of molecular biology" - an uncharacteristic judicial shrug of the shoulders by one of the Court's most opinionated members. ${ }^{130}$

\section{Understanding Myriad}

The Myriad case elicited strong, often visceral, reactions not only among lawyers, but also among scientists, healthcare advocates, cancer patients and their families. The case continues to fascinate and infuriate because it is "about" so many different things. It has layers upon layers of

\footnotetext{
124. Id. at 591 .

125. Id. at 583 .

126. Id. at $582-83$.

127. Id. at 591 .

128. Id. at 595 .

129. Id. at 594 (the Solicitor General's compromise position was first raised in the Department of Justice's amicus brief submitted to the Federal Circuit). The remarkable nature of the Department of Justice's brief, which largely opposed the position of the PTO, is discussed at length in Tejas N. Narechania, Defective Patent Deference, 95 WASH. L. REV. 869, 871 (2020), Ben Picozzi, The Government's Fire Dispatcher: The Solicitor General in Patent Law, 33 YAle L. \& POL'Y ReV. 427, 434-37 (2014), and Arti K. Rai, Patent Validity Across the Executive Branch: Ex Ante Foundations for Policy Development, 61 DUKE L.J. 1237, 1240-42 (2012).

130. Myriad IV, 569 U.S. at 596 (Scalia, J., concurring in part and concurring in the judgment).
} 
meaning, like the skins of an onion that can be peeled back, one by one, to reveal what lies at its core.

\section{A. Three Layers of Meaning}

On its outer, most superficial, layer is a question of patent doctrine- $\mathrm{a}$ new twist on the old "product of nature" rule. This is the type of question often posed by technical legal cases, and it can be answered, one presumes, through the diligent, if not mechanistic, application of existing legal rules. In such cases, one can ask whether the court got it "right," and, if not, what flaws in its reasoning led it astray. That, however, is a technical question only. Had a question of patent doctrine been the only issue at stake in Myri$a d$, its result would have been of interest to a handful of patent lawyers and biotechnology analysts, and demonstrators would not have crowded the steps of the Supreme Court.

The next layer reaches the effect of the patents in question on health care, on the market, and on the individual women who desperately needed $B R C A$ testing. This human element underlies many patent cases, especially in the pharmaceutical area. Patents give their owners the exclusive right to control, and price, products that are often essential to life itself. On the other hand, in our market economy, new drugs will not spring into existence of their own accord. Achieving the right balance between access and innovation is perhaps the greatest challenge faced by the patent system. This layer of the onion elicits impassioned advocacy far more than technical questions of law.

Yet within Myriad lies a deeper layer still. This layer deals with Myri$a d$ 's connection to human genes. Genes hold a privileged place in our collective imagination and our notions of what it means to be human. They are the messengers of heredity, determining our physical features, our mental quirks, our susceptibility to disease. They link us to our families, our ancestors, broader social, ethnic, and regional groups, and, at the deepest level, to all living creatures on earth. And, as something with which we are born, and that we can never change (at least, not yet), we consider genes to be integral to our persona and our identities as human beings. Thinking about genes as different, as special, has been somewhat derisively called "genetic exceptionalism." But genes are exceptional in ways that other cellular systems and organs in our bodies are not. And for this reason, the notion of owning genes somehow shocks the conscience, or at least, gives one pause. A case about owning genes was bound to be trouble.

Discussions of Myriad often reach an impasse due to the number of issues swirling around it. In the remainder of this Part, I try to tease apart the different strands of this complex landscape. 


\section{B. Does This Story Have A Villain?}

In an often-quoted 2013 article, Bob Cook-Deegan and Lane Baldwin observe that the press and the academy cast Myriad as a "ruthless mercenary" and "a villain in the evolving narrative of biotechnology." ${ }^{131}$ Is this characterization fair?

The first thing to note is that Myriad did not do anything underhanded when it obtained patents covering the BRCA1 and BRCA2 genes. Myriad, the University of Utah, and their lawyers were following well-established rules and practices of the Patent Office which, by 1994, had been in place for at least a decade. Human-derived substances like insulin, human growth hormone and erythropoietin had long been patented with little objection from anyone. Likewise, the Patent Office was faithfully, if somewhat myopically, following guiding precedent from the Supreme Court's 1980 decision in Chakrabarty. "Anything under the sun made by man" was patentable, so long as it had "markedly different characteristics" from anything found in nature. According to the Patent Office, genes that were isolated and purified met this threshold. As a result, the issuance of patents on isolated human DNA had become routine and accepted practice.

Myriad was the first case in which the very notion of patenting human genes was challenged. Before that, there had been significant litigation over DNA-based patents, but those disputes all involved challenges to particular patents on technical grounds - novelty, obviousness, and the like. ${ }^{132}$ Nobody in the industry seemed interested in bringing down the entire house of cards by challenging the existence of gene patents as a general principle. It was for this reason that nearly every patent expert that Hansen and Simoncelli consulted thought that they did not stand a chance.

The second thing to recall is that the ACLU chose Myriad as its target for reasons that went well beyond the characteristics of its patents; reasons that were largely political and strategic rather than legal. In fact, even at the time the lawsuit was filed, most of Myriad's BRCA patents were old. By now, almost all of them would have expired. And following the public release of the full sequence of the human genome in the early 2000s, gene patents, as they were issued in the heyday of 1990s gene hunting, were artifacts of the past. Whether or not human genes were eligible for patent protection, any patent application that tried to claim a gene that was already

131. Baldwin \& Cook-Deegan, supra note 99.

132. See, e.g., Luigi Palombi, Gene Cartels: Biotech in the Age of Free Trade 276-78 (2009) (discussing erythropoietin litigation). In addition, cases also related to patentability challenges made on the basis of the utility of DNA sequences with no known function. See in re Fisher, 421 F.3d 1365, 1366 (Fed. Cir. 2005), supra note 55 and accompanying text. 
disclosed to the public was doomed to fail on more conventional grounds. ${ }^{133}$ So Myriad was the poster child for a legal campaign against an (admittedly bad) patenting practice, but Myriad was by no means the worst or only beneficiary of that practice. ${ }^{134}$

This is not to say that Myriad was a particularly benevolent company. Myriad was both aggressive and calculating when it came to its competitors. But these behaviors were no different than that of most successful companies, and corporate tactics rarely seem to influence public perception of a company. ${ }^{135}$ As Gold and Carbone note, "Myriad pursued a fairly traditional commercialization strategy," and that strategy involved patents, just as it did for every other company in the biotechnology and pharmaceutical sectors.

The final important thing to understand about this episode is that Myriad's patents never covered genes as they naturally exist inside the human body. As broad as Myriad's patent claims were (and they were much too broad), they only covered "isolated and purified" DNA, which, no matter how expansively those terms are interpreted, refer to forms of DNA that are produced in the laboratory. Even though Myriad's patents on the BRCA genes should never have been granted, it is important to be clear about what the patents actually covered. Many well-intentioned people believed, and were understandably upset, that Myriad owned an integral, invisible part of their bodies. But that simply was not the case.

\section{The Supreme Court's Opinion: Baby-Splitting Generally Is Not Good for the Baby}

In assessing the significance of Myriad, the first layer of the onion is doctrinal: did the Supreme Court get it right? Was the Department of Justice's and Justice Thomas's interpretation of the product of nature doctrine reasonable, and was it sufficient to overturn the Patent Office's longstanding practice of granting patents on human genes? ${ }^{136}$

133. See Christopher M. Holman, Will Gene Patents Derail the Next Generation of Genetic Technologies?: A Reassessment of The Evidence Suggests Not, 80 UMKC L. REV. 563, 582-83 (2012).

134. See SACGHS 2010, supra note 58 (describing far more extensive gene patent holdings and assertions by, for example, Athena Diagnostics).

135. For example, companies whose products are beloved by the public-Disney, Apple, Mattel, McDonald's - are also known to be highly litigious and ruthless in their business dealings.

136. I do not address the standing issues raised by the case, as the procedures for challenging the validity of patents have changed significantly since $A M P$ v. Myriad was filed in 2009. Today, virtually anyone can challenge a patent at the Patent Trial and Appeals Board (PTAB) under a procedure called "inter partes review" or "IPR". See 35 U.S.C. $\S \S 311-319$. 


\section{Distinctions with a Difference}

To understand Myriad, it is useful to set out the three key contrasts that Justice Thomas establishes when he talks about DNA and genes. Though he does not actually lay these out very clearly, and somewhat blurs the distinctions among them, they can help to elucidate the basis for what is and is not patent-eligible.

\section{a. Cellular Genes versus Isolated Genes ${ }^{137}$}

Cellular genes are those that exist within human cells. Hundreds of genes are strung together in long, double-helical strands called chromosomes. Lots of other DNA is interspersed between the genes, and all sorts of other molecules hang off them, like holiday lights on a wire. ${ }^{138}$ Along the chromosome, the genes and other DNA are attached end-to-end with covalent chemical bonds, which act as the strong "glue" that Judge Lourie at the Federal Circuit found so important. An isolated gene, on the other hand, is just the gene, detached from the rest of a chromosome, and lacking most of its hanger-on molecules. Generally speaking, isolated genes do not exist in the body in any useful form. ${ }^{139}$

\section{b. Genomic DNA (gDNA) versus Complementary DNA (cDNA)}

In contrast to the distinction between cellular and isolated geneswhich relates to the positioning of a gene among other surrounding molecules - the distinction between gDNA and cDNA relates to what is "inside" a particular gene. Every human gene contains both exons (DNA that codes proteins) and far more numerous introns (DNA that does not code proteins). The fundamental difference between gDNA and cDNA relates to the presence of introns: gDNA has both exons and introns, while cDNA has only exons. ${ }^{140}$ Genes as they exist in the body are gDNA, as they include both

137. For the sake of discussion, I refer to "isolated and purified" genes, as referenced throughout the case, as "isolated".

138. We are slowly learning more about the function of the molecules that ride along with DNA. This is the study of epigenetics, which is still in its infancy. See SIDDHARTHA MuKHERJEe, THE GeNE: AN INTIMATE History 393-410 (2016).

139. Eric Lander, in an amicus brief, pointed out that certain pathologies can give rise to the existence of free-floating segments of DNA (possibly genes) in the human bloodstream. Brief of Eric S. Lander as Amicus Curiae in Support of Neither Party at 14, Myriad IV, 569 U.S. 576 (No. 12-398). Likewise, the ACLU pointed out in its brief that a segment of the $B R C A 1$ cDNA does occur naturally in the human genome (a so-called pseudogene). Brief for Petitioners at 51, Myriad IV, 569 U.S. 576 (No. 12-398).

140. It is important to remember that there are a large number of introns in every gene. For example, the BRCA1 gene has a total of about 125,000 bases. Only 5,000 of those are exons that code proteins. The other 120,000 are introns. Suppose that a particular protein (a receptor that is activated by a chemical found in catnip) is coded by a sequence of the three DNA nucleotides: C-A-T. In the gene, these three coding nucleotides (exons) are likely 
exons and introns. gDNA also exists in the lab - the isolated-purified genes mentioned above are often gDNA. However, DNA molecules that consist only of exons, known as cDNA, do not exist naturally within the body and can only be constructed in the lab. ${ }^{141}$

\section{c. Naturally-Occurring versus Synthetic}

This distinction relates to the way in which something is made. Was it created through natural means (i.e., by the body), or in the lab? Though this distinction is often raised in discussions of the "product of nature" doctrine, unlike the other two distinctions noted above (cellular versus isolated genes, gDNA versus cDNA), the distinction between naturally- and syntheticallycreated DNA, to the surprise of many, did not factor into Justice Thomas's analysis of patentability.

\section{The Court's Conclusions}

With these three bases for comparison firmly in mind, we can analyze the Supreme Court's approach to patent eligibility. Interestingly, the Court's opinion, which attempted to follow the government's lead in splitting a particularly colicky baby, has been criticized in equal measures both by supporters and opponents of gene patenting.

\section{a. Genes are Not Patentable Just Because They are Isolated}

First, Justice Thomas tackled the significance of isolating genes. In the 1980s, the Patent Office adopted a literalist interpretation of Section 101, embracing the argument that isolating DNA from a human cell transforms it into a new composition of matter. ${ }^{142}$ As such, it was patentable, like a new type of steel alloy or polymer. As Rebecca Eisenberg has pointed out, the first issued patents on human DNA covered the production of artificial proteins like insulin and erythropoietin, which resembled drugs more than any-

spread out and interspersed with non-coding nucleotides (introns), like this: AATCAGGGACCTGAT. Without those extraneous introns, the sequence consists of just the exons: CAT.

141. The body also makes a chemical that codes for proteins without the intervening introns, but this chemical is RNA, not DNA, and RNA is slightly different than DNA.

142. This argument also disregards a line of older Supreme Court precedent holding that purified forms of naturally occurring substances are not patentable. See Am. Wood Paper Co. v. Fibre Disintegrating Co., 90 U.S. 566, 594 (1874) [hereinafter The Wood-Paper Patent] (while purified wood pulp is not patent-eligible, the novel process for extracting pulp as well as new boiler designs were eligible for patent protection), Gen. Elec. Co. v. De Forest Radio Co., 28 F.2d 641, 643 (3d Cir. 1928) (purified tungsten not patentable), Cochrane v. Badische Anilin \& Soda Fabrik, 111 U.S. 293, 311-13 (1884) (purified alizarine (a natural red dye) not patentable), in re Marden, 47 F.2d 958, 1059 (C.C.P.A. 1931) (purified vanadium not patentable), and ex parte Latimer, 1889 Dec. Comm'r Pat. 123, 125 (1889) (purified pine needle fibers not patentable). 
thing else. ${ }^{143}$ Because patents on traditional, small-molecule drugs are a mainstay of chemical patent practice, it was a small conceptual leap to accept the same framework for protecting these synthetic biological compounds. It was only later, when companies like Myriad emerged, that patents started to claim complete human genes for no other purpose than to diagnose particular diseases and to stop others from doing so. And by then, it was too late. The floodgates had been opened.

Justice Thomas began his analysis with the test developed by the Court in Chakrabarty: is the substance under consideration "markedly different" than anything that occurs in nature? ${ }^{144}$ He first observes that the nucleotide sequences of isolated genes (the precise order of the As, Ts, Gs, and Cs) are identical to the sequences of cellular genes. And given that these sequences are the same, isolated genes are not "markedly different" than cellular genes. Therefore, isolated genes are not patentable (see Figure 2a).

Under this theory, it does not matter that isolated genes are detached from the larger chromosome or lack the other molecules that hang onto cellular genes in the body. Those chemical differences are what Judge Lourie at the Federal Circuit viewed as paramount (see Figure 2b). But Justice Thomas dismisses them as unimportant, or at least, not rising to the level of a marked difference. To him, the real purpose of genes is to encode proteins, and in that regard, only the nucleotide sequence matters.

Many of those who favored gene patenting criticized this reasoning. Some remained fixated on the chemical differences between isolated and cellular genes. To them, the breaking of covalent bonds is key-it creates new and different chemical compounds. ${ }^{145}$ Yet as Judge Sweet noted in his opinion, "scientists in the fields of molecular biology and genomics have considered this practice a lawyer's trick." The chemical differences between a gene in the body and the same gene isolated in the lab are irrelevant to the "informational" purpose of genes. The Supreme Court was correct in disre-

143. See Rebecca S. Eisenberg, Why the Gene Patenting Controversy Persists, 77 ACAD. MED. 1381, 1381 (2002). These early DNA patents differed from the abandoned patent applications filed by NIH and others to protect the short DNA segments known as ESTs. See supra notes 52-55 and accompanying text. They are also different from later "gene patents" inasmuch as they did not seek to claim the entire DNA sequence of a human gene, but the production of a protein by inserting a coding segment of human DNA into a bacterium or other organism for large-scale replication.

144. Rebecca Eisenberg and other scholars have wondered why the existence of a substance in nature should matter to the patentability of a synthetic compound that is clearly made by man. After all, how do we know what exists in nature throughout the universe? When scientists develop what they believe to be an entirely new polymer compound, should it matter that the compound is later discovered frozen beneath the ice cap of some extrasolar planet? If so, why?

145. For example, hydrogen chloride $(\mathrm{HCl})$ is a relatively harmless gas formed from covalently-bonded hydrogen and chlorine atoms. But when hydrogen chloride is bubbled through water, the covalent bonds between the hydrogen and chlorine atoms break, forming hydrochloric acid, a different substance indeed. 
garding these differences to eliminate the decades-old legal fiction that allowed patenting of human genes as new compositions of matter, simply because they are chemically altered from their counterparts in the body.

\section{b. A Synthetic Copy of a Natural Substance is Not Patentable Either}

A different objection to Justice Thomas's reasoning was raised by critics like Gene Quinn. In a blog post on the day of the Supreme Court's decision, ${ }^{146}$ Quinn argued that synthetic substances should be patentable, even if they are identical to substances that exist in nature. Take, for example, an artificial kidney grown in a test tube. It needs to be "indistinguishable from what appears in nature" in order to resist rejection by the host body into which it is transplanted. Shouldn't the artificial but otherwise-found-innature kidney be patentable? The Supreme Court said no.

A real-life example of Quinn's hypothetical example arose in Myriad's 2014 patent infringement suit against Ambry and other diagnostic labs that started to perform $B R C A$ testing immediately after the Supreme Court's decision. ${ }^{147}$ This time around, Myriad asserted patent claims covering short DNA primers that are necessary to perform diagnostic testing. Though the primers were clearly synthetic, both the district judge and the Federal Circuit held that they were unpatentable because they duplicated the exact DNA sequence of the cellular genes that they targeted. The fact that the primers were synthetic was irrelevant. Because they were the same as something occurring in nature, they were not patentable. ${ }^{148}$

Objecting to this result, critics argued that society will lose out on lifesaving innovations if we do not offer patent protection to their developers. Yet the Court recognized that patents should be available for innovative methods of creating even otherwise-found-in-nature substances. ${ }^{149}$ Thus, if Myriad had developed a novel method of locating mutations in the $B R C A$ genes, or of using them in a diagnostic test (which it did - see below), then a patent might have been available. But that is a different matter than patenting the biological product itself. Ultimately, the Court ruled that if the

146. Gene Quinn, Supremes Rule Isolated DNA and Some cDNA Patent Ineligible, IPWATCHDOG (Jun. 13, 2013, 8:24 PM), https://www.ipwatchdog.com/2013/06/13/supremesrule-isolated-dna-and-some-cdna-patent-ineligible.

147. Univ. of Utah Rsch. Fund v. Ambry Genetics Corp., 774 F.3d 755, 756 (Fed. Cir. 2014).

148. Id. at 761 ("[a] DNA structure with a function similar to that found in nature can only be patent eligible as a composition of matter if it has a unique structure, different from anything found in nature. Primers do not have such a different structure and are patent ineligible") (internal citation omitted).

149. See, e.g., The Wood-Paper Patent, 90 U.S. 566, 594 (1874) (while purified wood pulp is not patent-eligible, the novel process for extracting pulp as well as new boiler designs were eligible for patent protection). For a recent overview of the law of method or process patents, see generally Timothy R. Holbrook, Method Patent Exceptionalism, 102 IowA L. REV. 1001, 1005-06 (2017). 
product is the same as something found in nature (no matter how innovative the method of producing it), then no patent is available for the thing itself.

Accordingly, if Quinn's lab-grown kidney is identical to a human kidney, then no patent is available. This is the case even though a novel method of growing a synthetic kidney would be patent-eligible. ${ }^{150}$ This result is both reasonable and consistent with practice in many other industries. For example, there are thousands of patents covering improved methods for manufacturing unpatented articles - everything from rubber tires to salt pellets to electronic components, most of which have been around long enough that their patents, if they ever existed, are now expired. Nevertheless, because of market demand, manufacturers have continued ample incentives to keep developing even better methods of production, whether these are superior in terms of speed, cost, sustainability, worker safety or anything else. And if a competitor copies a patented method of manufacture, the patent holder can unequivocally assert its rights in court. ${ }^{151}$

Likewise, there are thousands of patents covering improved agricultural methods - methods of growing crops faster, eradicating pests and weeds, and yielding bigger and healthier tomatoes, figs, cattle, and salmon. All of these inventive methods are patentable, but the resulting fruits, vegetables and livestock, so long as they are genetically the same as their naturally occurring cousins, are not. And like manufacturers, agricultural scientists have ample incentives to keep improving even without patents on the fruits, literally, of their labor.

But what about more esoteric compounds, like synthetic antibodies? Shouldn't we grant a patent to the scientists who have developed a new lifesaving antibiotic that is identical to that produced by healthy immune systems? The answer and the logic behind it, are the same as they are for kidneys, salt tablets and avocados-no. If the synthetic antibodies are identical to the antibodies produced by the human immune system, then they should not be patentable. If the process or method used to develop, create, or manufacture them is novel, then it should be patentable. But if the method is simply a routine method used throughout the field, or a novel method that is

150. This precise argument was made, and the same result reached, by the Federal Circuit in a 2014 case involving Dolly the sheep. The Scottish Roslin Institute that created Dolly, the first viable cloned mammal, received U.S. patents on both the method of cloning a mammal as well as the cloned offspring themselves. The Federal Circuit held that while the Institute's method claims were allowable, the claims covering the sheep were not, given that, under the Supreme Court's ruling in Myriad, the cloned sheep were identical (by definition) to sheep found in nature (i.e., the original sheep from which they were cloned). In re Roslin Inst. (Edinburgh), 750 F.3d 1333, 1337 (Fed. Cir. 2014).

151. We even have a law that allows a patent owner to bring a U.S. patent infringement suit against the producer of an unpatented article that is manufactured outside the United States using a process that is patented inside the United States. See 35 U.S.C. § 271(g). 
patented by someone else, then the developers of the synthetic antibody should not be entitled to any patent at all. ${ }^{152}$

But won't this defeat the incentive system, meaning that no one will then choose to develop those lifesaving antibodies? It is unlikely. The biotech firm Genentech faced this very issue when it considered how to protect the synthetic insulin that it developed. ${ }^{153}$ Precisely because synthetic insulin was identical to natural insulin, Genentech did not pursue a composition of matter patent on it. Yet it was able to patent the process for making synthetic insulin, and as observed by Siddhartha Mukherjee, the patent "soon [became] one of the most lucrative, and most hotly disputed, patents in the history of technology." 154

But if the method of creating some synthetic substance - insulin, antibodies, or kidneys - is truly routine, then anybody should be able to use that method to create the same synthetic substances and more. In that case, the absence of patents should result in more, and cheaper, antibodies, as the same absence permits generic drugs to be produced at a fraction of the cost of drugs that are under patent. ${ }^{155}$ Likewise, the difficulty of finding a naturally-occurring substance should have no bearing on whether the substance itself is patentable. That is like saying that the Amazonian explorer who spent six months hacking through the jungle with conventional machetes deserves a patent on the mushroom that he discovers deep in the jungle, simply because it was hard to find. Such mushrooms, analogous to these methods, are products of nature and are not the kind of "inventions" that patents were intended to cover.

Finally, some critics have observed that it can be difficult, if not impossible, to prove in practice that a patented method is being used to create a synthetic product because factories and production plants are often locked down and their employees are under strict contractual obligations not to reveal the processes used within. It would be far easier, they argue, to point to the resulting synthetic kidney, antibody, or other substance and prove that it

152. It is true that detecting the infringement of a manufacturing process is often more difficult than detecting an article of manufacture that is identical to a patented article. Yet this practical evidentiary difficulty should not drive the substantive outcome of the law. Rather, procedures could be considered to inspect manufacturing operations that are suspected of infringing legitimate patents.

153. MUKHERJEE, supra note 138, at 245.

154. Id.

155. The issue of regulatory approval is a separate, but important, one. Proponents of patent protection argue that bringing the synthetic antibody to market will require significant FDA approvals involving expensive and lengthy clinical trials that would not be affordable without the back-end assurance of exclusivity arising from patents. This may, from a practical standpoint, be true. Yet this reality argues more for reform of the FDA approval system than the patent law. That is, if a synthetic substance can be shown to be identical to a substance occurring in nature, then perhaps a new and more lenient FDA approval process should be adopted. 
infringes a patent. This point is well-taken, and it is clearly easier to prove infringement by a product that one has in hand than by a manufacturing process conducted at some secret location. But patent laws are not designed for the convenience of litigants, and they should not be bent to overcome evidentiary inconvenience. There are ample discovery mechanisms within the civil litigation system to adduce evidence of infringement by a manufacturing process, and potential difficulties in that area do not justify changing the law to allow patenting of synthetic substances that are identical to those found in nature.

\section{c. $c D N A$ is Patentable}

So much for those who would have preserved the patentability of human genes. What about those on the other side of the aisle; the ACLU allies who criticized Justice Thomas for allowing patents claiming cDNA? In a single paragraph, Justice Thomas concluded that "cDNA does not present the same obstacles to patentability as naturally occurring, isolated DNA segments." Why not? Because, he reasoned, cDNA lacks the introns found in naturally occurring gDNA. Without the introns, cDNA is "something new"- a molecule that is created by the lab technician; it is not a product of nature. ${ }^{156}$ Hence, it is patentable.

156. Myriad IV, 569 U.S. at 595. It is also worth noting that when comparing isolated and cellular genes, Justice Thomas applies the "markedly different" test articulated by the Court in Chakrabarty. Id. at 590-91 (citing Diamond v. Chakrabarty, 447 U.S. 303, 310 (1980)). But when comparing cDNA to gDNA, he simply refers to cDNA as "something new"- a standard based on simple novelty rather than degree of difference. See Joshua Sarnoff, Religious and Moral Grounds for Patent Eligible Subject Matter Exclusions, in PATENTS ON LIFE 38, 54 (Thomas Berg et al. eds., 2019) ("the Court applied the "markedly different' standard ... to hold isolated DNA ineligible (while applying a different standard, 'creat[ing] something new,' to hold complementary DNA [cDNA] eligible)."). 


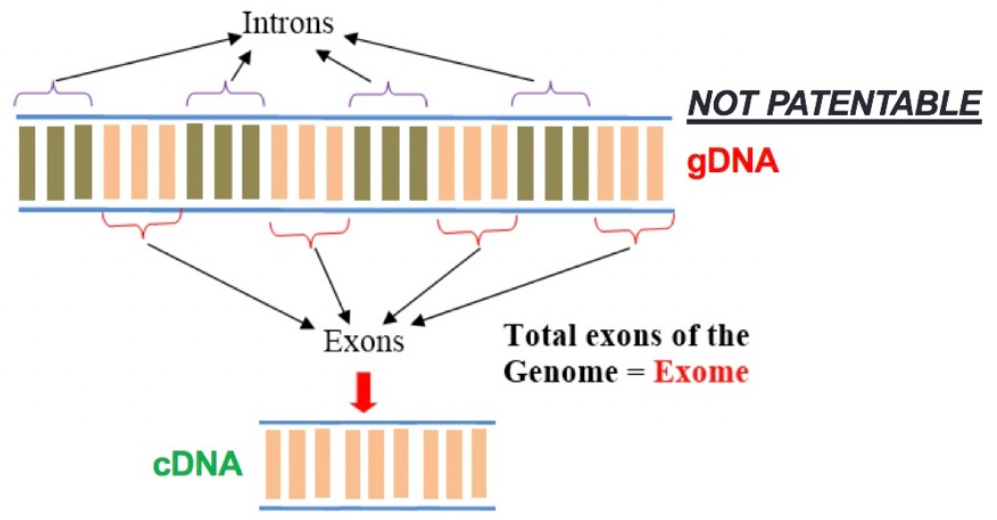

PATENTABLE

FIGURE 3

A Graphical Representation of the Difference Between Genomic DNA (GDNA) ANd COMPLEMENTARY DNA (CDNA) (SOURCE: THE Author)

This particular leap of logic has attracted the ire of scholars who have analyzed Justice Thomas's opinion. ${ }^{157}$ What was wrong with his reasoning? Just cast your eyes up a few paragraphs and you will see where Justice Thomas belittles the chemical differences between isolated genes and cellular genes. He finds these differences immaterial to the information content of the genes, so these two substances are not markedly different. Hence, no patent on isolated genes.

But if differences like covalent bonds and attached molecules do not make isolated DNA markedly different from cellular DNA, then why does the absence of introns distinguish cDNA from gDNA? After all, just like the missing covalent bonds in isolated DNA, introns are not relevant to the coding function of a gene. ${ }^{158}$ The same exons occur in both gDNA and cDNA in the same order, and both will code the same protein. It is just that the cDNA version lacks the introns interspersed among the exons. But the body's

157. See, e.g., Burk, supra note 9, at 507-08 (calling the distinction "at best incoherent"); Rai \& Cook-Deegan, supra note 9, at 137 ("The Court's analysis does not connect the dots as to why claims to information in the form of cDNA are less problematic than claims to information in the form of gDNA.").

158. And, as Professor Rebecca Eisenberg once pointed out to me during a discussion of this case, the addition or deletion of introns within a gene can have a significant impact on the coding properties of the gene-so-called shift mutations that can potentially alter the bases that are "read" to code proteins. 
DNA replication process nicely ignores those introns and replicates the information only from the exons. So, if we ignore covalent bonds to reason that isolated DNA is not patentable, then why don't we also ignore the absence of introns in cDNA?

In other words, if the important thing about DNA is its informational content - the order of As, Ts, Cs and Gs - and we ignore other chemical differences that are unrelated to this information, then shouldn't we ignore introns? Because if we do, both gDNA and cDNA should be unpatentable.

The magic microscope just does not work here. Or, if it does, it's not being properly focused, because neither isolated gDNA nor cDNA is chemically identical to what exists inside the body. Yet the Court treats one as patentable (cDNA) and the other as unpatentable (gDNA). There is really no principled, scientific reason to distinguish between molecules attached to cellular DNA, on one hand, and introns that are interspersed among the coding exons of a gene, on the other hand. Both are equally irrelevant to protein coding, and cDNA should not be eligible for patent protection. ${ }^{159}$

\section{Reining in "Invention"}

I agree with the Supreme Court's decision in Myriad inasmuch as it prohibits the patenting of isolated human genes (though, as mentioned above, I would have extended the ruling to cover cDNA as well). But even as to gDNA, I would have gone further than Justice Thomas, whose entire analysis rests on the "markedly different" test established in Chakrabarty. For reasons both rhetorical and analytical, I would have returned to the roots of patent law-the U.S. Constitution.

The Constitution authorizes Congress to grant patents to "inventors" for their "discoveries." ${ }^{160}$ The Patent Act says that patents will be granted to "whoever invents or discovers any new and useful ... composition of matter." Invention is at the root of the patent law. Did Myriad "invent" the $B R C A$ genes? Not under any reasonable interpretation of the word. ${ }^{161}$

159. Some commentators have argued that the most meaningful difference between gDNA and cDNA is not a scientific one, but a commercial one. Whereas the primary use for isolated gDNA is in genetic diagnostic tests (a comparatively small market), cDNA may be useful in a wide range of therapeutic and biotechnology applications. See Rai \& CookDeegan, supra note 9, at 137; Peter Lee, The Supreme Court's Myriad Effects on Scientific Research: Definitional Fluidity and the Legal Construction of Nature, 5 U.C. IRVINE L. REV. 1077, 1112 (2015); Burk, supra note 9, at 510; Arti Rai, Diagnostic Patents at the Supreme Court, 18 Marq. InTELl. Prop. L. REv. 1, 7 (2014). While this is likely true, it seems that there ought to be a better and more reasoned basis for a legal rule than its potential commercial impact. After all, opinions will differ regarding the commercial impact of one rule or another, and commercial facts are generally even more difficult to establish than scientific ones.

160. U.S. CONST. art. I, $\S 8$, cl. 8.

161. This argument is a simplified version of the one that Professor Joshua Sarnoff advanced in an amicus brief to the Supreme Court that fifteen law professors, including myself, 
Though Myriad was the first to isolate and sequence the $B R C A$ genes, it did not invent the genes themselves. In fact, at the time that Myriad sequenced the $B R C A$ genes, neither Myriad nor anyone else even knew their biological function. ${ }^{162}$ As Judge Bryson wrote in dissent at the Federal Circuit, Myriad's location of the BRCA genes was simply not "an act of invention."

Thus, at most, Myriad discovered (invented) a method for assessing a person's risk of cancer based on the presence of certain mutations in the $B R C A$ genes. Justice Thomas, echoing Judge Bryson, did not rule out patents claiming, "new applications of knowledge about the BRCAl and $B R C A 2$ genes" (emphasis in original). In fact, he acknowledged that several of Myriad's patents that were not challenged in the litigation did cover such applications of knowledge.

The disease-correlated mutations in the $B R C A$ genes were Myriad's actual contribution to science and probably should have been eligible for patenting (more on this below). But by allowing Myriad to claim the entire $B R C A 1$ and BRCA2 genes and all of their uses, both known and unknown, the Patent Office went too far. Again, Myriad did not invent the genes.

Allowing patents on genes as compositions of matter had far-reaching effects and gave Myriad far more than it deserved based on its actual discovery. This is just how composition of matter patents work. Suppose that someone invents and patents a new rubbery elastic compound called "flubber." ${ }^{163} \mathrm{He}$ has exclusive rights to every possible use of flubber - in bouncing balls, car bumpers, roof caulking, athletic shoes, and whatever else can be imagined.

Should someone who discovers a new gene have the same broad rights as the inventor of a new substance like flubber? Myriad's composition of matter patents covering the $B R C A 1$ and $B R C A 2$ genes gave it exclusive rights not only to conduct diagnostic testing using those genes, but to do anything else imaginable with those genes. A $B R C A 1$ antibody to fight tumor cells? Patented. Using $B R C A 2$ to predict the occurrence of birth defects? Patented. An endless number of applications and uses for those genes, none of which were discovered by Myriad, are all covered by the broad patents

signed. Brief of Fifteen Law Professors as Amicus Curiae in Support of Petitioners at 34-38, Myriad IV, 569 U.S. 576 (No. 12-398).

162. All that Myriad knew at the time it identified the $B R C A$ genes was that there was a correlation between a handful of mutations in the genes and an increased risk of breast or ovarian cancer. The mechanisms behind that correlation were completely unknown then. And, as the Federal Circuit held in in re Fisher, a DNA sequence with unknown function lacks patentable utility. 421 F.3d 1365, 1366 (Fed. Cir. 2005); see supra note 55 and accompanying text. Today, we know that the proteins encoded by the $B R C A$ genes are tumor suppressors. When the genes are damaged, they cannot code these proteins correctly, which allows tumors to grow unchecked. The mechanisms for these effects, however, are complex and still not wholly understood.

163. "Flubber," of course, is inspired by the mediocre 1997 movie of the same name starring Robin Williams. FLUBBER (Walt Disney Pictures 1997). 
claiming the genes as a compositions of matter. ${ }^{164}$ Yet this makes little sense, given that unlike flubber, Myriad did not invent $B R C A$ genes. Myriad merely discovered that they were useful in a particular applicationpredicting cancer risk. ${ }^{165}$

Patents arising from the discovery of gene-disease associations should always have been limited to the discovery actually made and should never have been allowed to expand to cover human genes as compositions of matter. Human genes are quintessentially products of nature, not inventions.

\section{Hold the Mayo: What About Methods?}

Above, I argue that those who discover a particular gene-disease association should not be permitted to claim the entire gene as a composition of matter, but should be permitted to obtain patent protection for their specific discovery - in the case of Myriad, the association of particular BRCA mutations with elevated risks of breast and ovarian cancer. This reasoning is supported by Justice Thomas, who makes it clear that his opinion does not relate to "new applications of knowledge about the BRCA1 and BRCA2 genes." The patentability of new applications of laws of nature finds its roots in Supreme Court decisions going back to the 1940s. ${ }^{166}$

Yet all but one of Myriad's method claims were rejected, even by the patent-friendly Federal Circuit. Why? Because the Supreme Court's decision in Mayo v. Prometheus changed everything with respect to diagnostic method claims. In Mayo, as in the earlier cases, Justice Breyer acknowledged that the Court must "determine whether the claimed processes have

164. This broad scope was useful to Myriad, as it granted Eli Lilly an exclusive license to develop therapeutic drugs using the $B R C A$ genes in exchange for significant up-front payments. Nevertheless, neither Lilly nor Myriad ever discovered any meaningful therapeutic use for the $B R C A$ genes.

165. One popular economic theory developed by Edmund Kitch in the 1970s compares patent rights to land claims in mineral prospecting. In order to encourage efficient exploration for minerals, the government parceled out tracts of land to private parties, with the understanding that these parties would have strong incentives to prospect their own parcels, either individually or by subleasing portions to those better equipped to do so. Edmund W. Kitch, The Nature and Function of the Patent System, 20 J.L. \& ECON. 265, 266 (1997). This "prospect theory" has frequently been used to justify the grant of broad patent rights to single companies, though I and others have argued that it does not lead to optimal development of new technologies. See Jorge L. Contreras \& Jacob S. Sherkow, CRISPR, Surrogate Licensing, and Scientific Discovery, 355 SCIENCE 698, 698-700 (2017).

166. See, e.g., Funk Bros. Seed Co. v. Kalo Inoculant Co., 333 U.S. 127, 130 (1948) ("If there is to be invention from [a discovery of a law of nature], it must come from the application of the law of nature to a new and useful end."); Diamond v. Diehr, 450 U.S. 175, 187 (1981) ("[A]n application of a law of nature or mathematical formula to a known structure or process may well be deserving of patent protection.") (emphasis omitted). See also Joshua D. Sarnoff, Patent-Eligible Inventions After Bilski: History and Theory, 63 HASTINGS L.J. 53, 81-83 (2011) (discussing history of provisions of the 1952 Patent Act pertaining to the patentability of newly discovered uses of known processes). 
transformed ... unpatentable natural laws into patent-eligible applications of those laws." But in doing so, he seemingly raised the bar on what counts as a "new application" of a natural law. In particular, in order for a patent to issue, he required that there be some "inventive concept" above and beyond the natural law and its application through "well-understood, routine, conventional activity." 167 Thus, the Court in Mayo held that a patent claiming a method for adjusting a patient's drug dosage based on the level of metabolites in the patient's blood was merely a straightforward application of a natural correlation observed in the human body. It was thus ineligible for patent protection. ${ }^{168}$

Mayo and the many lower court decisions following it have left the genetic diagnostics industry bereft of patents. ${ }^{169}$ Thus, while Myriad eliminated patents seeking to claim human genes as compositions of matter, Mayo eliminated patents on many applications of knowledge arising from the observation of human genes. But it is not only genetic diagnostics that have been affected. Recent judicial rulings have severely limited patents on other biomedical innovations such as new antibodies. ${ }^{170}$ Is this too much?

Critics of these cases argue that the unavailability of patents on human genes and related biotech discoveries will hinder the progress of science, and that we need patents to encourage companies to take risks and spend large amounts on R\&D. ${ }^{171}$ Without the carrot of exclusivity hanging just within reach, who would, or could, afford to spend a billion dollars to discover the next miracle cure?

This concern is a legitimate one. Clearly, the potential profits to be made by patenting $B R C A 1$ and $B R C A 2$ motivated Myriad to search for the

167. Some critics have argued that the new Mayo test implicitly introduces a new nonobviousness element to the determination of patent eligibility under Section 101 of the Patent Act, sidestepping the more constrained and nuanced non-obviousness analysis under Section 103 that has been developed over the years. Rebecca S. Eisenberg, Diagnostics Need Not Apply, 21 B.U. J. SCI. \& TECH. L. 256, 266-67 (2015). In my view, the Mayo requirement of a new invention beyond "mere application" of a natural law goes well beyond the analogous "markedly different" standard that the Court applied to products of nature in Chakrabarty.

168. The Federal Circuit's prior test allowed the claims in Mayo because they resulted in a physical "transformation" in a patient's body. I would not return to the Federal Circuit's peculiar "machine or transformation" test either.

169. See Eisenberg, supra note 167, at 266-68.

170. See Jacob S. Sherkow, Adaptive Intellectual Property 39 (Dec. 25, 2019) (unpublished manuscript) (on file with author) (explaining that "[a]ntibody patents in the U.S. have recently faced a reckoning from the U.S. Court of Appeals for the Federal Circuit. After decades of being able to patent antibodies with only loose - if not minimal - restrictions on sequencing information, the Federal Circuit significantly cracked down on the practice in 2017 in Amgen v. Sanofi.").

171. See, e.g., Greenwood, supra note 10 ("The past 25 years have seen an unprecedented explosion of research and scientific publication on the human genome and the genomes of bacterial and viral pathogens. New biologic medicines, vaccines and tests have become available to treat previously untreatable conditions, benefit patients and improve medical care. These developments were not impeded by patents - they were aided by patents."). 
genes. Without the promise of patents, Myriad would have never been formed or funded. ${ }^{172173}$ Perhaps then the Supreme Court's test for patent eligibility is too strict - not under Myriad (where, as I have argued above, it is still too permissive), but under Mayo. The requirement under Mayo that an application of a truly novel discovery cannot be patented unless the discoverer adds some invention above and beyond application of the discovery may ask too much. It is the intent of the patent laws, and of the Constitution, that useful and non-obvious applications ${ }^{174}$ of truly novel discoveries be eligible for patent protection, ${ }^{175}$ provided that patents are limited to the specific application(s) of the discovery made by the inventor, and not expanded to anything else that a skilled patent lawyer can dream up through artful claim drafting. ${ }^{176}$

172. The BRCA genes would almost certainly have been discovered whether or not Myriad had been formed. In the race to discover these particular genes, competing academic labs were never far behind Myriad and its collaborators. Prominent researchers like Mary-Claire King and Francis Collins, who had already contributed substantially to the search for the $B R C A$ genes, would have found them eventually, even without the extra capital and equipment brought to bear by Myriad. In the case of BRCA2, Michael Stratton's lab in London was on Myriad's heels, losing the race to publish the genetic sequence by a single day. So denying Myriad a patent on these discoveries would hardly have impacted scientific progress. Academic labs had other incentives to find the $B R C A$ genes, including the promise of greater governmental grant funding and the enhancement of their academic reputations (as ACLU's counsel wryly noted during oral arguments-Nobel Prizes). But the facts of Myriad are not typical. In most other scientific fields, groups of government-funded academic labs are not furiously racing to make the same discovery. In these areas, without companies that are incentivized to conduct R\&D by the promise of exclusivity down the road, some lifesaving discoveries might not be made. And this is not ideal either.

173. For discussions of the incentives that universities and other non-profit institutions have to make discoveries, see, e.g., Lisa Larrimore Ouellette \& Rebecca Weires, University Patenting: Is Private Law Serving Public Values?, 2019 Mich. St. L. Rev. 1329 (2019); JACOB RoOKSBy, THE BRANDING OF THE AMERICAN Mind: How UNIVERSities CAPTURE, Manage, And Monetize Intellectual Property And Why It Matters (2016); Lisa Larrimore Ouellette, Patentable Subject Matter and Nonpatent Innovation Incentives, 5 U.C. IRVINE L. REV. 1115 (2015); Eisenberg, supra note 167, at 283-84; SACGHS 2010, supra note 58 , at 35,90 .

174. Though the debate over patentability of genetic tests has largely focused on the hurdle of patentable subject matter under Section 101 of the Patent Act, the requirement that inventions be non-obvious under Section 103 is not trivial either. See SACGHS 2010, supra note 58 , at $68-71$; Holman, supra note 133 , at 581 .

175. This theory is best summed up by Professors Jeffrey Lefsin and Peter Menell in their amicus brief supporting the grant of certiorari in Sequenom, Inc. v. Ariosa Diagnostics, Inc., 788 F.3d 1371 (Fed. Cir. 2015), cert. denied, 136 S. Ct. 2511 (2016), a case in which a truly revolutionary breakthrough was denied patent protection because it embodied a "law of nature". Regrettably, the Supreme Court declined to hear the case. It is discussed more fully in Thomas F. Cotter, Patent Wars: How Patents Impact OuR Daily Lives 105-106 (2018). See also Michael Risch, Nothing Is Patentable, 67 FLA. L. REV. F. 45, 45-47 (2015) (critiquing the scope of the inventive application test).

176. I cannot emphasize enough the need for patent claims to be drawn narrowly to the actual and specific discoveries made. Over-claiming, as encouraged by the Kitch prospect theory (see Kitch, supra note 165, at 266) tends to pre-empt too many uses of a natural law or 
Under a liberalized Mayo standard for method claims, Myriad would have been entitled to a patent claiming a method of predicting an elevated risk of breast or ovarian cancer in a patient by detecting specified mutations in her $B R C A$ genes. The claims would not have covered the entire gene, nor would they cover any mutations of the gene not specifically disclosed (i.e., discovered) by Myriad, nor would they cover any use or application of those genes other than the ones specifically spelled out by Myriad. We should permit patents for claims that fall within those narrow confines. ${ }^{177}$

This approach resonates with earlier Supreme Court precedent like $D i$ amond v. Diehr in which the Court upheld a patent on a new method for curing rubber that was based on the well-known Arrhenius equation. ${ }^{178}$ The equation itself was not patentable, but its application in the narrow context of curing rubber was viewed as an invention eligible for patent protection. This result must be what Justice Breyer intended when he described patents on "applications of natural laws" in Mayo.

So where would such a modified test for method claims leave us? Among other things, Myriad would still have patents covering $B R C A$ testing. Even without broadly claiming $B R C A 1$ and $B R C A 2$ as compositions of matter, method claims like these would have enabled Myriad to lock up the $B R C A$ testing market - at least for mutations discovered by Myriad - as it did for many years. ${ }^{179}$ The end result for patients and competing labs would have been the same-limited access, no competition, high prices. And that is not ideal either.

But we shouldn't blame the patent system for all of the world's woes or twist the patent system into unnatural configurations in order to avoid them. These problems arise not only from the existence of patents, but from other systemic issues that can and should be addressed. Two of the biggest culprits are the university licensing system and the healthcare payment system.

\section{E. All Hail, Alma Mater}

When Mark Skolnick and Peter Meldrum formed Myriad in 1991, their first step was to secure rights to all breast cancer genetic discoveries made by Skolnick's university lab. The University agreed to license any patents arising from those discoveries exclusively to Myriad, enabling Myriad to

relationship, thus dampening innovation that might otherwise occur. See generally Katherine J. Strandburg, Much Ado About Preemption, 50 Houston L. REV. 563 (2012).

177. For a variety of reasons, Myriad's European $B R C A$ patents were generally limited to this narrow scope. See Eliot Marshall, BRCA2 Claim Faces New Challenge, 308 SCIENCE 1851 (2005).

178. Diehr, 450 U.S. at 193. Other decisions, however, reject the patentability of arguably inventive applications of natural laws. See Parker v. Flook, 437 U.S. 584, 590 (1978), Gottschalk, 409 U.S. at 71-73.

179. What Myriad would have lost is the ability to license other applications of the BRCA genes (e.g., therapeutics) to companies like Eli Lilly. 
exercise nearly complete control over them. In return, the University received a small share of Myriad stock, $\$ 250,000$ in cash, and a $\%$ royalty on Myriad's future $B R C A$ testing revenue. ${ }^{180}$ Of course, with a successful product like BRACAnalysis, this royalty became significant. Court documents show that, over their lifetime, the University of Utah earned about $\$ 40$ million from the $B R C A$ patents. ${ }^{181}$

When, in the mid-1990s, Myriad and the University made clear their intention to obtain patents on the $B R C A$ genes, there was an outcry from other academic groups. Mary-Claire King, publicly decried the fact that a university had exclusively licensed its patents to Myriad, effectively permitting a company to win the race to find BRCA1. ${ }^{182}$ There was a strong suggestion that if King at Berkeley or Francis Collins at the University of Michigan had won the $B R C A$ race, the controversy over the resulting patents would never have arisen.

There may be some truth to this suggestion, though less, perhaps, than its proponents may wish to believe. The liberal licensing models to which King, Collins and others pointed were established in the 1980s, during the early days of university technology transfer. The CFTR gene associated with cystic fibrosis was discovered in 1989 by a team of researchers including Collins. The University of Michigan and Hospital for Sick Children applied for a patent, then licensed that patent on a non-exclusive, royalty-free basis to any lab that wanted to test the gene. ${ }^{183}$ A similar situation existed with the HEXA gene for Tay-Sachs disease, which was discovered at NIH in 1984. NIH obtained a patent on the gene but chose to make licenses available without charge. ${ }^{184}$

Not quite so magnanimously, Stanford University and the University of California, which held patents on recombinant DNA techniques, licensed those patents for a modest fee. Over the life of the patents, the universities granted 468 licenses earning them more than $\$ 250$ million. ${ }^{185} \mathrm{~A}$ few years later, Columbia University adopted a similar approach with its patents cov-

180. The University separately agreed in 1995 to split this royalty with NIH, which was also a co-owner of several of the foundational BRCA patents.

181. In re BRCA1- \& BRCA2- Based Hereditary Cancer Test Patent Litig., 3 F. Supp. 3d 1213, 1220 (D. Utah 2014).

182. Jane Gitschier, Evidence Is Evidence: An Interview with Mary-Claire King, 9 PLOS GENETICS 1, 4-5 (2013).

183. For an in-depth discussion of the patenting and licensing of the CFTR gene, see Misha Angrist et al., Impact of Gene Patents and Licensing Practices on Access to Genetic Testing for Long QT Syndrome, 12 GENETICS IN MED. S111 (2010); Mollie A. Minear et al., Cystic Fibrosis Patents: A Case Study of Successful Licensing, 48 LES NOUVELLES 21 (2013).

184. For an in-depth discussion of the patenting and licensing of the Tay-Sachs gene HEXA, see Alessandra Colaianni, Subhashini Chandrasekharan \& Robert Cook-Deegan, Impact of Gene Patents and Licensing Practices on Access to Genetic Testing and Carrier Screening for Tay-Sachs and Canavan Disease, 12 GENETICS IN MED. S5 (2010).

185. Robert Cook-Deegan \& Christopher Heaney, Patents in Genomics and Human Genetics, 11 ANN. REV. GENOMICS \& HUM. GENETICS 383, 392 (2010). 
ering DNA cotransformation, from which it earned nearly $\$ 800$ million. ${ }^{186}$ While the recombinant DNA and cotransformation patents were hugely profitable, the universities that held them adopted a broad strategy of licensing on a non-exclusive basis to the entire field. This strategy worked because these universities correctly anticipated that recombinant DNA and DNA cotransformation could be used by every genetics lab in the world as they were generally applicable research tools. ${ }^{187}$

This is not the case with gene patents. Unlike generally applicable research tools like recombinant DNA techniques, there are far fewer potential licensees for a patent that covers a particular disease-related gene. Thus, unlike the 468 licenses that Stanford and UC granted under their recombinant DNA patents, the owner of a disease-related gene patent might expect to find fewer than a dozen commercial and university labs willing to pay for a non-exclusive license. The financial return from such a licensing program would be small.

Prevailing wisdom in the technology licensing industry holds that a single exclusive licensee will often pay more than a slew of non-exclusive licensees. And while the institutions that held the CFTR and HEXA patents chose to make them available to others without charge, that altruistic approach was quickly supplanted in the 1990s by more profit-oriented strategies. Thus, as illustrated by Table 1 in Part I.B, most gene patents were licensed exclusively to companies seeking to earn both testing and licensing revenue from them. In fact, Mary-Claire King's university at the time, UC Berkeley, sought to patent her initial mapping of BRCAl to chromosome 17 and exclusively licensed that patent to the company OncorMed. Likewise, the Cancer Research Centre in the United Kingdom, which patented discoveries made by Michael Stratton's group during the race to find $B R C A 2$, granted OncorMed an exclusive license to its European $B R C A 2$ patents. So despite the high-minded protestations of these prominent researchers, their own institutions followed more or less the same strategy as the University of Utah in granting exclusive rights in the $B R C A$ genes to a chosen compa-

186. Alessandra Colaianni \& Robert Cook-Deegan, Columbia University's Axel Patents: Technology Transfer and Implications for the Bayh-Dole Act, 87 MiLBANK Q. 683, 683 (2009).

187. Academics as well as NIH policy makers have urged the non-exclusive licensing of research tools since the 1990s. See Principles and Guidelines for Recipients of NIH Research Grants and Contracts on Obtaining and Disseminating Biomedical Research Resources: Final Notice, 60 Fed. Reg. 72090 (Dec. 23, 1999); Michael A. Heller \& Rebecca S. Eisenberg, Can Patents Deter Innovation? The Anticommons in Biomedical Research, 280 SCIENCE 698 (1998). This being said, some have criticized the licensing of these technologies on a royaltybearing basis whether exclusive or non-exclusive, noting that royalties paid to universities seldom promote the dissemination of the technologies, and simply inure to the financial benefit of the universities. Rebecca S. Eisenberg \& Robert Cook-Deegan, Universities: The Fallen Angels of Bayh-Dole?, 147 DAEDALUS 76, 78 (2018) (comparing payments made on platform technologies to a tax on innovation). 
ny. ${ }^{188}$ It was through a combination of luck and shrewd business strategy that Myriad was able to acquire OncorMed's rights to these patents after sparring with the company in litigation for several years.

Thus, Myriad and hundreds of companies like it obtained exclusive license rights to patented university technologies with very few strings attached. Jacob Sherkow and I coined the term "surrogate licensing" in 2017 to describe an arrangement in which a research institution effectively relinquishes all of its rights in a patented technology to a private company, and abdicates its corresponding responsibilities to the same company. ${ }^{189}$ Billions of dollars in federal research funding flow to U.S. research institutions, many of which patent their discoveries and license them to private companies to do what they wish.

Universities are, by and large, non-profit organizations chartered to pursue charitable and educational goals. Companies are not. When universities divest their technology to surrogate companies in exchange for financial remuneration, they effectively cede discretion over the use and exploitation of that technology to the private sector. Unlike university trustees, company directors have a duty to maximize the financial return to their shareholders, not to provide affordable healthcare or medical technology to those in need. Social goals like these are the province of government and charitable enterprises, including universities.

So, if companies like Myriad take aggressive stances regarding pricing and access to their products, they are only acting as companies do. Do not blame the tiger for behaving like a tiger, blame the careless guards who allowed the tiger to roam free in the village. It is the public organizations operating in the background or, more precisely, failing to act, that are equally responsible for any inequities that result from the commercial exploitation of publicly funded R\&D.

Take, for example, Myriad's commercialization of the BRCA genes. As described above, there was significant criticism of the company's exclusion of competitors, high pricing, and broad promotion of its test to the public. Much of this criticism came from government officials - Collins and Varmus, in particular. And recall that, though NIH was one of the earliest applicants for patents on human DNA segments, it reversed that position in 1994 , soon becoming one of the leading opponents of DNA patenting.

188. Today, in fact, UC Berkeley is regarded as one of the most aggressive and profitoriented universities engaged in academic technology transfer. In 2017, Sherkow and I wrote about Berkeley's stunning license of all of its rights in the revolutionary CRISPR-Cas9 gene editing technology to a privately-held company called Caribou Therapeutics. Contreras \& Sherkow, supra note 165.

189. Contreras \& Sherkow, supra note 165, at 698-99 ("These surrogates control a large and lucrative field for the exploitation of the licensed technology, and have significant freedom both to exploit it themselves and to seek partners and sublicensees. The surrogates take on the role of the patent owner and retain a lion's share of the resulting profits."). 
Against this backdrop, few remember that NIH was part-owner of several of Myriad's BRCA1 patents due to work that two NIH scientists performed in collaboration with Myriad during the race to discover the gene. Varmus himself gave control of those patents to Myriad in 1995 when he settled a dispute over "inventorship" of the gene. ${ }^{190}$

And in the 1980s, NIH even tried to rein in drug pricing by requiring a "fair pricing" clause in all of its cooperative R\&D agreements ("CRADAs") with private industry. This mandatory contractual language, widely reviled by the pharmaceutical industry, was adopted by NIH in response to a controversy surrounding the AIDS drug AZT. ${ }^{191}$ The drug, which was released in 1987 by Burroughs Wellcome, bore the then-stratospheric price tag of $\$ 8,000$ per year. ${ }^{192}$ Yet, as AIDS activists were quick to point out, Burroughs Wellcome had not been the one to discover the drug nor its effectiveness against AIDS. A failed cancer treatment, AZT's potential use against AIDS was first suspected by scientists at NIH's National Cancer Institute. To encourage Burroughs to bring AZT to market, NIH allowed the company to retain full ownership of the resulting patent. But once that happened, there was no way to constrain Burroughs' pricing of the drug, and it charged what it felt the market would bear.

To prevent further instances of price gouging, in 1989 NIH inserted a new fair pricing clause into all of its CRADAs, requiring that there be a "reasonable relationship between the pricing of a licensed product, the public investment in that product, and the health and safety needs of the public." ${ }^{193}$ But in Varmus's view, despite its worthy aims, NIH's fair pricing clause had little impact on drug pricing. Instead, it seemed to make companies reluctant to cooperate with government labs, or at least to sign agreements with them. Which would be preferable, he must have asked, a highminded pricing policy that resulted in little or no collaboration with the government, or more collaboration without the fair pricing policy? Ever the pragmatist, in 1995, Varmus decided to eliminate the fair pricing clause

190. See Skolnick, supra note 73; Rachel Nowak, NIH in Danger of Losing Out on BRCA1 Patent, 266 SCIENCE 209, 209 (1994).

191. Lauran Neergaard, NIH Drops 'Reasonable Price' Clause for Drug Company Collaboration, ASSOCIATED PRESS (Apr. 11, 1995), https://apnews.com/article/0fda3df8eb $88951 \mathrm{~d} 7 \mathrm{ec} 747 \mathrm{e} 5 \mathrm{db} 381 \mathrm{f} 7 \mathrm{f}$.

192. Compared to today's astronomical prices for the latest gene therapy treatments, some of which can exceed $\$ 2$ million, the $\$ 8,000$ price tag for AZT seems quaint. Yet, at the time, the New York Times called AZT "the most expensive prescription drug in history." Opinion, AZT's Inhuman Cost, N.Y. TIMES, Aug. 28, 1989, at A16.

193. Marlene Cimons \& Victor F. Zonana, Manufacturer Reduces Price of AZT by 20\%, L.A. TIMES (Sept. 19, 1989), https://www.latimes.com/archives/la-xpm-1989-09-19-mn-111story.html. 
from NIH's standard research agreement, reasoning that this would better "promote research that can enhance the health of the American people.,"

If the federal government had truly been committed to the fair pricing of biomedical innovations, it could have held its ground in early negotiations with the pharmaceutical industry and Myriad. It is particularly difficult to understand how a multi-billion-dollar government agency could have capitulated so completely to the demands of a tiny Utah-based start-up that had not yet released a product or earned a single penny of revenue. There is no good reason why NIH's license agreement with Myriad contained no safeguards regarding pricing of or access to any BRCA-related inventions. ${ }^{195}$

The same sins of omission can be attributed to the University of Utah. In multiple agreements with Myriad, the university gave Myriad complete discretion over exploiting the $B R C A$ patent rights-largely funded by federal grants - that emerged from the university. So long as the university received its royalties, it reserved no right to control or approve any aspect of Myriad's commercial program.

Perhaps this lack of oversight was forgivable, or at least understandable when Myriad was formed and its first license agreements with the university were signed in 1991. Those were still the early, heady days of university technology transfer. Institutions across the country were salivating at the thought of blockbuster profits from the next Genentech or Biogen. The University of Utah, in particular, aspired to such prominence, recalling the success of the Jarvik-7 artificial heart program, coupled with a desperate need to redeem itself after the humiliating and costly cold fusion fiasco. Utah's TTO officials did not know in 1991 whether Myriad, then merely a gleam in Mark Skolnick's eye, would ever amount to anything, but at least they had avoided the worst excesses of the sweetheart deal offered to Pons and Fleischman for cold fusion.

But a dozen years later, in 2003, when Myriad had patented both the $B R C A 1$ and BRCA2 genes and eliminated all competition in the field of $B R C A$ testing - when news exposés about the company had already appeared in Nature ${ }^{196}$ and the Boston Globe Magazine ${ }^{197}$ — a growing chorus of

194. Neergaard, supra note 191. See also Press Release, Official Announcement of Termination of "Fair Pricing" CRADA Clause, NAT'L. InST. HEALTH: NIH NEws (Apr. 11, 1995) https://www.ott.nih.gov/sites/default/files/documents/pdfs/NIH-Notice-RescindingReasonable-Pricing-Clause.pdf. The issue of "fair" drug pricing continues to be a top priority issue in the United States.

195. Over the years, NIH has exhibited a surprising reluctance to seek distributional and access goals for federally-funded technologies, particularly its never-asserted "march-in" rights under the Bayh-Dole Act. See John R. Thomas, Cong. Rsch. SERV., R44597, MARCH-In Rights UNDER THE BAYH-DOLE ACT 8-10 (2016).

196. Lori B. Andrews, Genes and Patent Policy: Rethinking Intellectual Property Rights, 3 NATURE REV. GENETICS 803 (2002).

197. Kimberly Blanton, Corporate Takeover: Exploiting the US Patent System, A Single Company Has Gained Control Over Genetic Research and Testing for Breast Cancer. And 
researchers, genetic counselors and bioethicists criticized the company's policies, ${ }^{198}$ and a major government task force raised concerns about the impact of gene patenting on research and patient care. ${ }^{199}$ The university could and should have done better. In that year, the University of Utah fought Myriad over unpaid royalties and Myriad's failure to assign patents under the terms of their agreements. A formal arbitration commenced, and in settlement, Myriad paid the University $\$ 3.5$ million and assigned it rights to 23 patents. ${ }^{200}$ The University then immediately licensed those patents back to Myriad under the terms of their original 1991 agreement.

Had the university focused instead on promoting public health rather than its own financial gain, it could have imposed additional requirements on Myriad when it settled the dispute in 2003. Those requirements could have included effective pricing ${ }^{201}$ and access concessions, permitting second opinion or confirmatory testing, and a requirement that Myriad continue to share $B R C A$ variant data with the research community. ${ }^{202}$

Scientists, Doctors, and Patients Have to Play by its Rules, Boston Globe Mag., Feb. 24, 2002.

198. See, e.g., Cho et al., supra note 89, at 3-8; Eisenberg, supra note 143, at 1382; Debra Leonard, Medical Practice and Gene Patents: A Personal Perspective, 77 ACAD. MED. 1388 (2002); Sara Chandros Hull \& Kiran Prasad, Reading Between the Lines: Direct-toConsumer Advertising of Genetic Testing, 9 REPROD. HEALTH MATTERS 44 (2001).

199. The SACGHS task force was established "in the fall of 2002 to formulate advice and recommendations on the range of complex and sensitive medical, ethical, legal, and social issues raised by new technological developments in human genetics, including the development and use of genetic tests" and to study gene patenting, in particular. SACGHS 2010, supra note 58, at ix. The impact of Myriad's policies and patents on scientific research is discussed in Lee, supra note 159, at 1088-98.

200. Settlement Agreement \& Mutual Release by and between Myriad Genetics, Inc. and the University of Utah Research Foundation and the University of Utah (Mar. 31, 2004) (on file with the author).

201. The issue of pricing in healthcare markets is a complex and fraught one, and there is no single contractual mechanism that can solve it. Nevertheless, some contractual commitment to price products at "fair" levels could help. First, one could ask whether Myriad's pricing for BRACAnalysis was fair. There is evidence to suggest that it was not. Both its impressive profit margins prior to the Supreme Court decision (approaching $90 \%$ for diagnostic testing) and Mark Skolnick's incriminating on-film admission in the 2007 documentary In the Family suggest that there was room for a price reduction. In other work, I have explored the notion of "fair, reasonable, and nondiscriminatory" (FRAND) pricing in markets for patents on technical interoperability standards. Certainly, there is no universal agreement on what those prices should be, or what the term FRAND really means. The result has been extensive litigation among smartphone, semiconductor and computer networking makers. Nevertheless, solutions are possible, as courts have gradually addressed these FRAND commitments case by case, and more global solutions, such as non-governmental rate-setting, have been proposed. See Jorge L. Contreras, Global Rate-Setting: A Solution for Standards Essential Patents?, 94 WASH. L. REV. 701 (2019).

202. While it was predictable that it would do so, Myriad did not actually discontinue participation in the public Breast Cancer Information Core (BIC) until 2004. Baldwin \& Cook-Deegan, supra note 99 , at 8 . 
And lest you think that such contractual commitments are radical or unusual, they are not. In fact, Myriad was well aware of them, as the UKbased Cancer Research Centre imposed access conditions on OncorMed in its license of the BRCA2 patents - a license that Myriad acquired in its 1998 settlement with OncorMed.

The trend for research universities to exert greater control over their surrogate licensees' commercial behavior has begun to pick up steam in recent decades. In 2007, the heads of eleven major U.S. research institutions including Harvard, Yale, MIT and the University of California, committed to abide by a set of core intellectual property licensing values known as the "Nine Points." ${ }^{203}$ These include commitments by the universities to require that their licensees make research tools as broadly available as possible, to grant exclusive licenses sparingly, to facilitate access to health-related technologies in the developing world, and the like. To date, over one hundred universities and other research institutions around the world, including the University of Utah, have committed to abide by the Nine Points. ${ }^{204}$

So-called "ethical licensing" by research institutions has attracted even greater attention recently with the development (and patenting) of CRISPR gene editing technology. ${ }^{205}$ The foundational CRISPR patents are held by Berkeley and the Broad Institute of Harvard and MIT (still being led by Eric Lander). In its patent licensing agreement with Monsanto, the Broad has prohibited the use of CRISPR technology in three controversial areas: the creation of gene drives, sterile "terminator" seeds, and improved tobacco products. Numerous other examples of voluntary commitments by patent holders to avoid undesirable activities - from agreeing not to transfer patents to "trolls" to refraining from enforcing patents against small businesses to charging 'fair, reasonable and nondiscriminatory' royalties - have all been documented in the literature. ${ }^{206}$

Likewise, it was not preordained that the University of Utah had to grant Myriad an exclusive license to its $B R C A$-related discoveries. As Sherkow and I acknowledge, exclusivity may be required to incentivize expen-

203. CAL. Inst. of TeCh. ET AL., In the Public Interest: Nine Points to CONSIDER IN LiCENSING UNIVERSITY TECHNOLOGY (2007) [hereinafter Nine POINTS].

204. A current list of signatories to the Nine Points document is maintained at https://autm.net/about-tech-transfer/principles-and-guidelines/nine-points-to-consider-whenlicensing-university.

205. Christi J. Guerrini et al., The Rise of the Ethical License, 37 NAtURE BioteCH. 22, 22 (2016). Another area in which the Nine Points have been cited in urging universities to exercise restraint in patent licensing is climate change. See Joshua D. Sarnoff, The Patent System and Climate Change, 16 VA. J.L. \& TECH. 301, 349-50 (2011).

206. See, e.g., Jorge L. Contreras, The Evolving Patent Pledge Landscape, 166 CENTRE FOR INT'L GOVERNANCE; INNOVATION PAPERS 1 (2018); PATENT Pledges: Global Perspectives on PATENT LAW's PRIVATE ORdeRING Frontier (Jorge L. Contreras \& Meredith Jacob eds., 2017). 
sive $R \& D$ efforts such as drug development, testing and approval. ${ }^{207}$ But this is not always so. Sometimes, as in the case of the BRCA genes, somebody would have discovered them even without the exclusivity promised by patents. Several competing groups almost did. So when a university is considering whether to grant a company exclusive or nonexclusive rights to its discoveries, it should consider two things: whether exclusivity is needed to ensure that the discoveries find their way into useful products, and whether the products themselves might achieve a greater social impact if they are available from multiple sources (e.g., a research tool like PCR that can be used by every lab in the world). I am not alone in arguing that if either of these factors weighs in favor of granting non-exclusive licenses, then universities, with their public missions in mind, should not grant exclusive rights to their discoveries, even if doing so might yield them greater shortterm profits. ${ }^{208}$

And what if universities lose sight of their public missions, the prospect of patent licensing riches luring them toward closer and closer ties to private industry? Perhaps NIH and other governmental funding agencies could take a more active role in nudging universities back toward their public missions. A large percentage of academic research in the United States is funded by the taxpayers; for example, in the 2020 fiscal year federal research funding agencies provided about $\$ 134$ billion in funding, with more than $\$ 39$ billion coming through $\mathrm{NIH} .{ }^{209}$ In 2019 , a team of researchers estimated that nearly

207. See Contreras \& Sherkow, supra note 165, at 699-700. See also Arti K. Rai \& Rebecca S. Eisenberg, Bayh-Dole Reform and the Progress of Biomedicine, 66 L. \& CONTEMP. PROB. 289, 300-03 (2003).

208. See, e.g., Ian Ayres \& Lisa Larrimore Ouellette, A Market Test For Bayh-Dole Patents, 102 CORNELL L. REV. 271 (2017) (arguing that the potential market for university technology should dictate whether it is licensed exclusively or non-exclusively); Brief of James D. Watson as Amicus Curiae in Support of Neither Party at 14, Myriad IV, 569 U.S. 576 (2013) (No. 09-CV-4515) ("If, for some reason, patents on human genes are deemed necessary, the next best, albeit imperfect, solution is to require those patent holders to license the patents to other researchers so that scientific progress is not obstructed."); NINE POINTS, supra note 203 (universities commit to limiting exclusive licensing of research tools); Nat'l. Human Genome Rsch. Inst., Best Practices for the Licensing of Genomic Inventions: Final Notice, 70 Fed. Reg. 18,413 (Apr. 11, 2005) (urging NIH-funded researchers to grant non-exclusive licenses with respect to broadly-applicable research tools); Rai \& Eisenberg, supra note 207, at 310 ("Congress should recognize that patenting and exclusive licensing are not always the best way to maximize the social value of inventions and discoveries made with federal funds."); Principles and Guidelines for Recipients of NIH Research Grants and Contracts on Obtaining and Disseminating Biomedical Research Resources: Final Notice, 64 Fed. Reg. 72,090, 72,093 (Dec. 23, 1999) ("Where the subject invention is useful primarily as a research tool, inappropriate licensing practices are likely to thwart rather than promote utilization, commercialization and public availability."); Heller \& Eisenberg, supra note 187 (arguing that patenting and exclusive licensing of broadly applicable research tools could lead to anticommons effects).

209. Cong. Rsch. SERV., R45715, Fed. Rsch. AND DeV. (R\&D) Funding: FY2020 (2020). 
one-third of U.S. patents arose from federally-funded research. ${ }^{210}$ Given this significant level of support, commentators over the years have wondered why the benefits of this research should flow primarily to private companies, rather than to the taxpayers. ${ }^{211}$ Couldn't funding agencies insist that research universities abide by the types of fair licensing practices discussed above?

As Rai and Eisenberg pointed out years ago, an amendment to the Bayh-Dole Act might be required to give funding agencies this authority. ${ }^{212}$ Such an amendment might be warranted today, particularly in the case of federally-funded research that is likely to have a significant effect on human health and welfare, like searching for the BRCA genes or a new COVID-19 vaccine. ${ }^{213}$ Even absent an amendment to the Act, governmental agencies could do more to encourage their grantees to act in the public interest, possibly through the long-neglected legal mechanisms of march-in rights and governmental use of patented inventions. ${ }^{214}$

Thus, when assigning blame for limited access, high prices and a lack of competition in the area of genetic diagnostic testing - not just for $B R C A$, but across the board - there is plenty to go around. Fault lies with the Patent Office, which adopted a particularly myopic interpretation of patent eligibility in allowing the patenting of human genes as compositions of matter, as well as the government agencies and universities that neglected to fulfill their public missions when granting a private company unrestricted exclusive rights to a valuable federally-funded discovery.

\section{F. Paying it Forward}

Another significant factor that limited access to Myriad's $B R C A$ test was pricing. Admittedly, Myriad's list price for BRACAnalysis, which rose

210. L. Fleming et al., Government-funded Research Increasingly Fuels Innovation, 364 SCI. MAG. 1139, 1139 (2019).

211. See Michael Sweeney, Correcting Bayh-Dole's Inefficiencies for the Taxpayer, 10 Nw. J. TECH. \& INTELL. PROP. 295, 295 (2012); Ana Santos Rutschman, Vaccine Licensure in the Public Interest: Lessons from the Development of the U.S. Army Zika Vaccine, 127 YALE L.J.F. 651, 651 (2018).

212. Rai \& Eisenberg, supra note 207, at 310 ("The time is ripe to fine-tune the BayhDole Act to give funding agencies more latitude in guiding the patenting and licensing activities of their grantees.").

213. Other proposals regarding taxpayer-funded research have also been made. See Sweeney, supra note 211, at 306-07 (proposing reimbursement of federal grant funding from the profits of resulting discoveries); Rutschman, supra note 211, at 663-64 (proposing an amendment to the Patent Act to prohibit exclusive licensing for vaccines and other critical technologies developed at public expense); Jorge L. Contreras, Expanding Access to Patents for COVID-19, in ASSESSING LEGAL RESPONSES TO COVID-19 158 (Scott Burris et al. eds., 2020).

214. See Jorge Contreras, Patents and Coronavirus - Compulsory Licensing, Government Use and March-In Rights, INFOJUSTICE (Mar. 28, 2020), http://infojustice.org /archives/42184. 
from $\$ 2,400$ in 1996 to about $\$ 4,000$ today, is not pocket change for most people. Yet these sums pale in comparison to the staggering figures that are being charged for the latest gene therapies, including the record-breaking \$2.1 million price tag that Novartis recently announced for Zolgensma, a gene-based treatment for spinal muscular atrophy (SMA).

The key, of course, is insurance coverage. Few families caring for children with SMA will pay the \$2.1 million price for Zolgensma, as most insurance policies in the U.S., as well as Medicare and Medicaid, will cover such treatments. But genetic testing for otherwise healthy individuals is more difficult to get covered. As discussed in Part I, it took Myriad nearly a decade to convince large insurance carriers to cover $B R C A$ testing, and then only with the imposition of strict eligibility requirements. It was clearly in Myriad's self-interest to persuade insurance carriers to cover $B R C A$ testing, and it did its best to do so. Eventually, this effort succeeded, and many of the tragic stories that emerged from the $B R C A$ testing debates will not likely recur.

This being said, pricing for medical services in the United States is in a state of crisis. Americans pay far more for healthcare than citizens of any other nation in the world, but in exchange for health outcomes that are middling at best. ${ }^{215}$ It is therefore incumbent upon federal and state legislatures, not the courts, to fix our overpriced healthcare system and ensure that every American has access to decent healthcare. This issue is far bigger than diagnostic genetic testing. It affects every American and should be fixed.

\section{Conclusion: Myriad and the Making of Common Law}

Setting aside patents and genetics, Myriad offers some broader lessons about general law and lawmaking. This remarkable case sheds fresh light on the rough-and-tumble manner in which the common law is made. ${ }^{216}$ The law is not, generally speaking, designed from the ground up, like a skyscraper or a computer chip. Rather, it accretes, case by case, judge by judge, like a gigantic coral formation far beneath the waves. Yes, there is a structure, a skeletal framework upon which individual cases must build. However, the

215. Diana Farrell et al., Accounting for the Cost of U.S. Healthcare: A New Look at Why Americans Spend More, MCKINSEY Global InSTITUTE, Dec. 1, 2008, at 10-11.

216. Despite its statutory basis, patent law is rife with gaps and open issues that must be filled by the courts. See Shyamkrishna Balganesh, The Genius of Common Law Intellectual Property, 48 J. LEG. STUD. (forthcoming) (manuscript at 2) ("Patent, copyright and trademark law in the U.S. are today seen as statutory areas that Congress alone is authorized to modify .... Yet, hidden away in the interstices of these statutory areas is a rather robust body of law that applies common law ideas, methods and principles to various informational resources without running afoul of preemption concerns."); Adam Mossoff, Statutes, Common Law Rights, and the Mistaken Classification of Patents as Public Rights, 104 IOWA L. REV. 2591, 2611 (2019) ("courts have created out of whole cloth new substantive legal rights not listed anywhere in the patent statutes"). 
randomness and sheer volume of human events effectively guarantee that no central planner can predict every set of circumstances that the law will need to resolve. ${ }^{217}$

This is especially true of jurisprudence surrounding scientific and technological development. The legal system offers a framework grounded in notions of fair play, justice and public welfare that is, I hope, flexible enough to adapt to the breathtaking pace of scientific advancement. Yet that adaptation does not happen overnight. Genetic diagnostics is just one example of a new technology that "broke" the legal system of the day, but the past is littered with examples of similar legal inflection points caused by technical advance - the telegraph, the railroad, the video recorder, the Internet, social media, GPS tracking. And there are more on the horizon-gene editing, artificial intelligence, augmented reality, autonomous vehicles, and interstellar travel (and advances that we haven't even begun to think about).

For better or worse, generalist judges are required to decide cases involving these new technologies. They don't always get it right. In some cases, as exemplified by Justice Scalia's short concurrence in Myriad, they might not understand all of the nuances of the particular technologies before them. Nevertheless, it is a hallmark of our democratic system that legal decisions, even those concerning the most complex technologies, are tried to lay juries and judges. They do their best, and, on balance, I think that our hybrid system is better than governance by specialists and technocrats alone. ${ }^{218}$ After all, it took non-experts like the ACLU attorneys who brought the case to recognize the legal absurdity of treating human genes as new compositions of matter. Excessive familiarity with a particular technical domain can sometimes blind one to otherwise obvious inequities.

This being said, judges and juries do not set out to design the law for future generations. Rather, they are charged with deciding the particular cases before them. They respond to the facts of these cases - the human stories that motivate them, that brought parties into collision and dispute. There are narratives behind every case. These narratives shape not only the outcome as to the parties such as who wins, who loses, who pays, who goes home empty handed, but they also shape the law as well. Nothing illustrates

217. The importance of randomness in forming legal doctrine cannot be understated, and there is no better example of this phenomenon than Myriad. In this case, the absence or alteration of any number of chance events might have affected the outcome, and the law, dramatically. Most importantly, maybe the chance appearance of a number of trained scientists in positions was critical to the outcome of the case. These individuals brought the perspective of the scientific community, which largely opposed gene patents, to bear from within organizational structures that ordinarily might have given a greater degree of deference to the expertise of the Patent and Trademark Office.

218. The U.S. system may be contrasted with that in Europe, in which many patent law determinations are made by the European Patent Office, an entity that has been characterized as "an autonomous, quasi-judicial technocracy." Aurora Plomer, The EPO as Patent LawMaker in Europe, 25 EUR. L.J. 57, 57 (2019). 
this point so well as Myriad, in which the different narrative strains developed by each of the players, including the scientists, the biotech industry, the patent establishment, the medical community and the cancer patients themselves, ended up shaping the reasoning used by the courts to decide the case. ${ }^{219}$

Myriad also demonstrates the often-under-appreciated impact of politics on our legal system. Some have criticized the significant role that NIH, OSTP, the Department of Justice, and other agencies played in the case. But I view this as a natural and positive feature of our legal system. Our three branches of government will continue to collide, collaborate, and collude to create new law and to change old law as it becomes obsolete. The law will inevitably adapt, though not without its fits and delays. And in many cases, the end result will not be perfect. This is not necessarily a bad thing, but it does lend a measure of unpredictability to the law, and to all of us who must live under it. Yet despite the hardships this unpredictability inflicts on some, it also leaves openings for the smart, the determined, the idealistic, and the lucky to seek change when change is needed most. The vast undersea formation that is the law evolves bit by bit, unpredictably and seemingly at random, until, when viewed from afar, it accretes into a majestic structure that is far larger and more valuable than its individual components, much like the human genome itself.

219. See Jorge L. Contreras, Narratives of Gene Patenting, 43 FLA. ST. U. L. REV. 1133 (2016) (classifying six distinct narrative strains across the Myriad cases). 